\title{
ANÁLISIS DE RESIDUOS ORGÁNICOS Y POSIBLES CONTENIDOS EN ÁNFORAS PÚNICAS Y TURDETANAS PROCEDENTES DEL VALLE DEL GUADALQUIVIR ${ }^{1}$ \\ Organic Contents from Punic and Turdetanian Amphorae of the Guadalquivir Valley
}

FRANCISCO JOSÉ GARCÍA FERNÁNDEZ, EDUARDO FERRER ALBELDA ${ }^{1}$ PALOMA ÁLVAREZ MATEOS ${ }^{1}$, MARÍA MONTAÑA DURÁN BARRANTES ${ }^{1}$

(1) Universidad de Sevilla.fjgf@us.es, eferrer@us.es,palvarez@us.es,mmduran@us.es

\section{RESUMEN:}

En este trabajo abordamos el estudio de los principales contenedores anfóricos que circularon en el Bajo Guadalquivir durante la II Edad del Hierro, cuáles eran los más representativos desde el punto de vista cuantitativo y, por tanto, los más elocuentes sobre los productos comercializados en los mercados turdetanos. Para ello se han tenido en cuenta tanto los recipientes de supuesta fabricación local (Pellicer B-C y Pellicer D) como los procedentes del ámbito púnico, especialmente la bahía de Cádiz y su hinterland (T-8.2.1.1 y T-8.1.1.2). Con las muestras obtenidas en las excavaciones en la calle Cilla (Alcalá de Río) y en Vico (Marchena), y exceptuando los envases de salazón de origen gaditano, los análisis de contenidos grasos indican que las ánforas T-8.1.1.2, contenían aceite de oliva, mientras que las ánforas "turdetanas" eran envases polifuncionales que podían transportar diversos productos (aceite de oliva, carnes en conserva, derivados lácteos) y/o ser reutilizadas.

Palabras clave: Ánforas, contenidos grasos, Bajo Guadalquivir, segunda Edad del Hierro.

\section{Abstract:}

This work presents the results of a study of amphorae contents in the Lower Guadalquivir Valley during the Second Iron Age. The questions addressed include the most common contents and, therefore, the most commonly commercialised products in Turdetanian markets. Both local (Pellicer B-C and Pellicer D) and Punic containers, especially from the Bay of Cadiz and its hinterland (T-8.2.1.1 and T-8.1.1.2), have been taken into consideration. The analysis of the remains recovered during the excavation of Calle Cilla (Alcala de Rio, Seville) and Vico (Marchena, Seville) reveal that amphorae T-8.1.1.2, manufactured in the rural areas of Cadiz, with the exception of those used for the storage and transport of salted products, were used to contain olive oil, as previously claimed, while 'Turdetanian' amphorae were multifunctional containers which could have been used to store a wide variety of products (olive oil, meat preserves, milk by-products) and/ or were reused.

Key words: Amphorae, fats, Lower Guadalquivir, Second Iron Age 
El estudio de los alimentos que se transportaban, almacenaban, preparaban y servían en los recipientes cerámicos constituye una importante línea de investigación en Arqueología desde hace más de 30 años (véase, por ejemplo, Cañabate y Sánchez 1995 o Evershed 2008a, con abundante bibliografía). El análisis de residuos orgánicos proporciona una información primordial para aproximarnos a la dieta de las sociedades pretéritas y acercarnos al uso de los repertorios cerámicos domésticos, especialmente a la relación entre tecnología, forma y función de los diferentes utensilios.

A pesar de las dificultades relativas a su conservación y extracción, estos estudios han demostrado que los fragmentos cerámicos pueden albergar una amplia variedad de compuestos, más o menos degradados dependiendo de su naturaleza y de los procesos deposicionales a los que se han visto sometidos. Los análisis sobre residuos orgánicos de las últimas décadas han ido ampliando la gama de productos, así como su relación con diferentes contenedores y usos. Algunos de los compuestos más reconocidos son aceites vegetales, grasas de animales, ceras, esteroles, resinas y aminoácidos o ácidos grasos, a los que se prestará especial atención en estas páginas (por ejemplo, Regert et al. 2003; Garnier 2007; Evershed 2008b; Garnier et al. 2011).

\section{OBJETIVOS}

Este trabajo se ha llevado a cabo en el marco del proyecto "Sociedad y Paisaje. Alimentación e identidades culturales en Turdetania-Bética (ss. VIII a.C. - II d. C.)" de la Universidad de Sevilla (HAR2011-25708/Hist). Su principal propósito ha sido la caracterización de los hábitos de consumo de las poblaciones del valle del Guadalquivir durante la II Edad del Hierro con el fin de aproximarnos a sus formas de vida, sus relaciones económicas y su organización social (Chaves et al. 2010). Ello nos ha permitido, asimismo, evaluar el papel que estas prácticas pudieron tener en la negociación de las identidades colectivas, muy especialmente en la construcción de fronteras simbólicas (sociales, étnicas, etc.) entre unas comunidades y otras (García Vargas y García Fernández 2009; García Fernández y García Vargas 2010; García Fernández 2012). Con el objeto de abordar las diferentes dimensiones que comprende la alimentación, como un proceso cultural significativo, se plantearon una serie de objetivos generales: 1) identificación de los tipos de alimentos consumidos y su procedencia; 2) definición de la dieta básica y su capacidad nutricional a partir, sobre todo, de la cantidad, variedad y periodicidad del consumo de los distintos alimentos; 3 ) estudio de las formas de preparación de los alimentos y su evolución a lo largo del tiempo, especialmente en relación con la introducción de modas de procedencia foránea; y 4) análisis de las pautas de servicio y consumo, así como sus implicaciones sociales y culturales.

En este sentido, la identificación de los productos y la definición de las redes a través de las cuales se distribuyeron y comercializaron los excedentes hacia los centros de consumo se impone como una prioridad a la hora de satisfacer de forma transversal los distintos objetivos, especialmente los alimentos básicos, cuyo transporte solía realizarse generalmente -aunque no de forma exclusivaen ánforas. La imposibilidad de detectar arqueológicamente otros contenedores, sobre todos los elaborados con materiales perecederos, como odres de piel o barriles de madera, nos obliga a fijar nuestra atención en aquellos recipientes como principal fuente de información paleoeconómica y comercial.

\section{ÁNFORAS DE LA II EDAD DEL HIERRO EN EL BAJO GUADALQUIVIR}

Partiendo de los anteriores objetivos, hemos tratado de abordar en este estudio los principales contenedores anfóricos que circularon en el Bajo Guadalquivir durante la II Edad del Hierro, los más representativos desde el punto de vista cuantitativo y, por tanto, los más elocuentes potencialmente sobre los tipos de productos comercializados en los mercados turdetanos y su origen. Para ello se han tenido en cuenta tanto los recipientes de supuesta fabricación local (márgenes del Guadalquivir y campiñas interiores) como los procedentes del ámbito púnico, especialmente la bahía de Cádiz y su hinterland (fig. 1). Hemos excluido, no obstante, aquellas producciones cuyo uso, así como su continuidad en el tiempo, ha quedado suficientemente demostrado por las investigaciones arqueológicas y/o los análisis arqueométricos, concretamente las ánforas destinadas al transporte de salazones o sus derivados, como las correspondientes a los tipos Mañá-Pascual A4 (G-11 y G12 de Ramon), Mañá C2b (T-7 4.3.2/T-7.4.3.3 de Ramon) y las clasificadas como CCNN o Campamentos Numantinos (T9.1.1.1 de Ramon). 


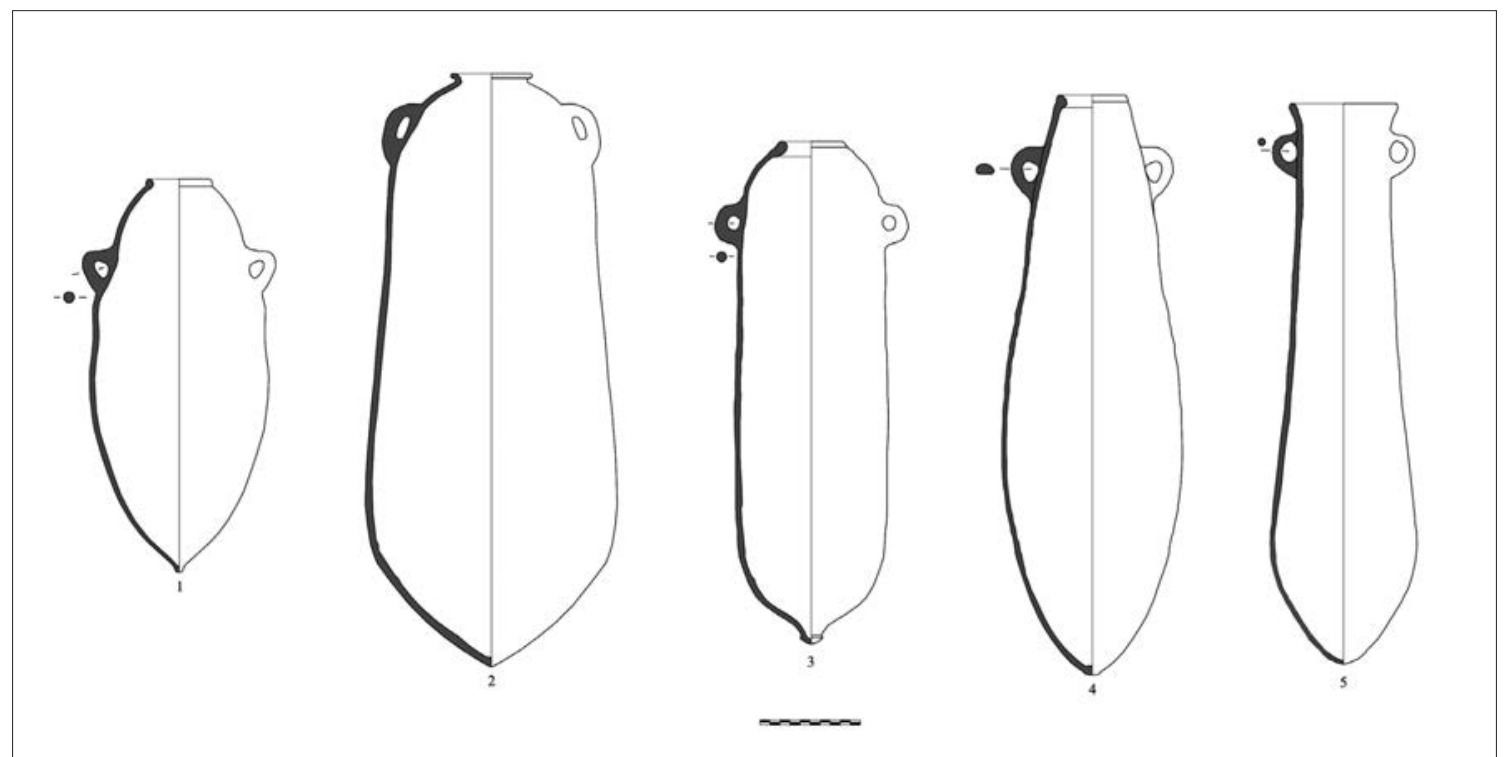

Fig. 1: Ánforas de la II Edad del Hierro en el valle del Guadalquivir: Pellicer C (1), Pellicer B (2), Pellicer D (3), T-8.1.1.2 (4) y T-8.2.1.1 (5).

\section{TIPOS B-C DE PELLICER}

También conocidas en la literatura como ánforas iberopúnicas (Pellicer 1978: 377) o iberoturdetanas, tradicionalmente se vienen considerando las producciones típicas turdetanas (Ferrer y García Fernández 2008: 211). Por lo que respecta a su génesis, derivan directamente de los contenedores fenicios arcaicos (T10.1.2.1 de Ramon), mientras que su desarrollo es paralelo al de los envases salazoneros de la costa malagueña y gaditana del grupo de las Mañá-Pascual A4, con las que comparte un origen común (Ferrer y García Fernández 2008: 211).

Se trata en realidad de dos tipos bien diferenciados a partir de la forma del cuerpo: uno de perfil troncocónico (tipo $\mathrm{B}$ ) y otro fusiforme $\mathrm{u}$ ovalado (tipo $\mathrm{C}$ ), con hombros poco marcados y fondos de tendencia cónica (Pellicer 1978: 377), si bien comparten la misma manera de solucionar el borde, lo que ha llevado a asociarlos en un mismo grupo, sobre todo cuando se trabaja con ejemplares muy fragmentados (Belén 2006: 219). Por lo general desarrollan bordes engrosados al exterior, separados del cuerpo por un estrangulamiento más o menos pronunciado y con una amplia variabilidad (secciones circulares, ovaladas, trapezoidales, e incluso molduradas en los ejemplares más tardíos), que podrían estar reflejando no solo la coexistencia de distintos talleres con rasgos propios, sino también una evolución en el tiempo paralela a la del propio recipiente (Pellicer 1978: 377-384).

Estas ánforas se empezaron a fabricar a finales del s. VI a.C., si no antes, manteniéndose en los contextos de consumo hasta la primera mitad del III a.C. (Ferrer y García Fernández 2008: 211). Aunque los complejos alfareros protohistóricos documentados hasta el momento en el valle del Guadalquivir son escasos (García Fernández y García Vargas 2012), y aún más las evidencias concluyentes sobre las cerámicas producidas, es muy probable que ánforas de estos tipos se fabricaran en los hornos exhumados en Cerro Macareno (Fernández Gómez et al. 1979; Ruiz Mata y Córdoba 1999) y en Carmona, en el área industrial aneja al arroyo Arbollón (Rodríguez 2001), si nos atenemos a los restos registrados tanto en los depósitos que amortizan estas estructuras como en los vertederos de alfar asociados al primer caso (Belén 2006: 236-240). Su distribución coincide a grandes rasgos con los límites de la región turdetana, pues se circunscribe básicamente al curso medio y bajo del Guadalquivir y sus campiñas adyacentes, las márgenes del llamado Lacus Ligustinus y las costas de Cádiz y Huelva, aunque también encontramos ejemplares con frecuencia en el litoral algarvio, Bajo Alentejo y N de Marruecos. 
Por el contrario, su función exacta es una total incógnita y, aunque se han vertido pocas opiniones al respecto, convencionalmente estos envases se han asociado a los excedentes agropecuarios producidos en las campiñas interiores y en las márgenes del Guadalquivir, sobre todo aceite y vino (Chaves et al. 2010: 1089).

\section{TIPO D DE PELLICER}

Desde finales del s. IV y durante el III a.C. los tipos B-C de Pellicer serán paulatinamente reemplazados por las ánforas correspondientes al tipo D (Pellicer 1978: 384). A diferencia de aquellas, se trata de recipientes de perfil totalmente cilíndrico, alargado, de hombros altos y fondo apuntado, con bordes entrantes de tendencia horizontal, solo marcados por un engrosamiento al exterior o al interior, en ocasiones separados por un ligero escalón (Ferrer y García Fernández 2008: 211). El propio Pellicer distinguió cuatro variantes a partir del perfil general del cuerpo, que tiende de la forma ojival de las primeras producciones a los envases de paredes rectas o ligeramente ensanchadas en su tercio inferior que caracterizan al tipo (Pellicer 1982: 390-392). Posteriormente Niveau de Villedary trató de realizar una clasificación a partir de la sección del labio diferenciando hasta ocho variantes; sin embargo no parece que se puedan establecer unas pautas cronológicas comunes, pues se han documentado ejemplares con bordes muy dispares en los mismos contextos, en ocasiones depósitos cerrados sin posibilidades de intrusiones de otras épocas (Niveau de Villedary 2002: 237). A pesar de ello, y como ya advirtiera Pellicer, sí se observa una propensión generalizada al estrechamiento y simplificación de los labios conforme avanza el tiempo, especialmente en el s. II a.C. (García y González 2007: 555). Las últimas producciones del s. I a.C. cuentan ya con labios planos y horizontales, totalmente indiferenciados de la pared, lo que permite ponerlas en relación con especímenes documentados en la costa portuguesa, denominados comúnmente Castro Marim 1 (Arruda 2001: 77-78).

No existe consenso acerca del origen de esta forma pero, a pesar de que se acepta casi unánimemente su producción en el Bajo Guadalquivir, al menos en momentos avanzados de su cronología, su presencia en el horno III de Kouass y en el alfar de Pery Junquera -aunque no se haya verificado su fabricación-, el hallazgo de ejemplares con pastas propias de la bahía de Cádiz y de Marruecos, o su distribución por la costa atlántica de
Andalucía, Portugal y Marruecos, podrían sugerir la génesis del tipo en el ámbito púnico-gaditano (Niveau de Villedary 2002: 241-242). De hecho, se ha planteado la posibilidad de que en su morfología convergieran las tradiciones locales con las centromediterráneas (Ferrer 1995: 803), adquiriendo su perfil cilíndrico, bien por influencia directa de las ánforas Mañá D (G-5 de Ramon), bien indirecta a través de contenedores occidentales, como los T-8.2.1.1, que paralelamente van adoptando también esta morfología (Niveau de Villedary 2002: 242), aunque en todo caso coincide con una tendencia común a las producciones anfóricas del Mediterráneo centro-occidental desde al menos inicios del s. IV a.C. (Ramon 1995: 286-287).

Su fabricación parece iniciarse a finales del s. IV, a partir probablemente de variantes evolucionadas de los tipos B-C con las que convivirá durante la primera mitad del s. III a.C., momento en el cual se convierte en el recipiente anfórico por excelencia de las comunidades del Bajo Guadalquivir, al menos hasta mediados de la siguiente centuria (García Fernández y García Vargas 2010: 118); su declive en esta región coincide precisamente con la creación de los primeros tipos propiamente béticos: Haltern 70, LC 67, Oberaden 83-Dressel 20, etc. (García Vargas 2009). No obstante raras veces se registran en contextos productivos, lo que dificulta determinar los alfares donde fueron elaboradas y sus redes de distribución. Hasta la fecha solo está constata su manufactura en Carmona, en un área industrial extramuros situada al N de la Puerta de Sevilla, donde se han identificado algunos ejemplares pasados de cocción junto con ánforas de tipología plenamente romanizada, procedentes de un vertedero de época tardorrepublicana, amortizado a su vez por sendos hornos datados en el cambio de Era (Ortiz y Conlin, e.p.). Aunque no existen pruebas concluyentes, es probable que se fabricaran también en el horno excavado en Pajar de Artillo, en Itálica (Luzón 1973: 47-48), y en el alfar documentado recientemente en los sótanos del Palacio Arzobispal de Sevilla (García Fernández y García Vargas 2012: 2125), si bien una vez más en ningún caso las fechas parecen remontar el s. II a.C. Las pastas, por su parte, apuntan hacia un amplio abanico de procedencias, lo que, unido a la abundancia de estos recipientes tanto en el entorno de la bahía gaditana como los centros urbanos situados en las márgenes del Guadalquivir, no permiten considerarla expresamente un producto local ni importado. 
Por lo que respecta a su función, se desconocen los productos que pudo transportar, ya que al igual que ocurre con su inmediata antecesora carecíamos hasta el momento de análisis sobre residuos orgánicos o recubrimientos interiores. Se ha especulado sobre la posibilidad de que transportaran vino o aceite (Miró 1983-84: 164), salazones de pescado (Ferrer 1995: 803) o algún tipo de alimento sólido, como aceitunas o cereales, sobre todo si tenemos en cuenta su morfología resulta poco apta para el envasado de líquidos (Niveau de Villedary 2002: 243); incluso es posible pensar, como veremos, en conservas de carne, si nos hacemos eco de los restos documentados en otras producciones cilíndricas coetáneas, especialmente sardas (Ramón 1995: 264). Tampoco hay que descartar que se pudiera tratar de un recipiente polifuncional, tanto en el sentido de no estar destinadas al transporte de un único producto, como en la posibilidad de que tuviera un uso secundario como recipiente de almacenaje (Niveau de Villedary 2002: 242). En ese caso, la dificultad para determinar un uso primario resulta aún más insoslayable, pues los resultados de los análisis de residuos orgánicos pueden estar enmascarando el contenido original bajo los restos de las mercancías introducidas en un momento posterior.

\section{RAMON T-8.1.1.2}

Mejor identificados parecen tanto el origen como el contenido de las ánforas T-8.1.1.2, conocidas comúnmente como tipo Tiñosa (Rodero 1991). Todo apunta a que su forma se inspira en las ánforas ebusitanas T-8.1.1.1 que circularon por las Baleares y el levante peninsular durante todo el s. IV a.C. (Ramon 1995: 222), cuyas variantes más evolucionadas (T-8.1.3.0) llegaron con relativa frecuencia a las costas gaditanas. Aunque se desconoce el contenido exacto de estas últimas, el hallazgo de varios ejemplares con restos de resina de pino en su interior podría relacionarlas con el transporte de vino, vinagre o alimentos conservados en este último, así como también conservas de carne o pescado en salazón (Tresserras y Matamala 2004: 285). Se trata en todo caso de un tipo totalmente nuevo tanto en los talleres como en los mercados surpeninsulares. El cuerpo presenta una tendencia general oval o bicónica, carente de hombros y sin aristas marcadas, y con el diámetro máximo en el tercio inferior. El cuello es en realidad una prolongación del cono superior por encima de las asas $\mathrm{y}$ remata en unos labios indiferenciados al exterior, marcados a lo máximo por una suave acanaladura, y engrosados al interior (Ramon 1995: 222). No se han individualizado hasta el momento variantes más allá de las diferencias en la sección y el tamaño del borde que se observan entre los distintos especímenes, y que no responden tanto a una evolución cronológica del tipo como a la coexistencia de distintos talleres o alfareros.

Casi todos los investigadores convienen en que su fabricación debió tener lugar en el entorno de la bahía de Cádiz, o incluso en la propia isla (Ramon 1995: 222). Aunque no se han hallado ejemplares en contextos de alfar ni tampoco restos mal cocidos o desechados que facilitaran al menos la localización de los centros de producción, los análisis arqueométricos dirigidos por $\mathrm{P}$. Carretero sobre un número significativo de individuos bien diagnosticados, tanto de la costa y las campiñas interiores de Turdetania como de otras procedencias como el Algarve (Castro Marim) o Alicante (Cap Negret, Altea), han permitido determinar un único grupo de pastas para el tipo (Carretero et al. 2004; Carretero et al. 2006). La práctica totalidad de las muestras presentan, pues, características técnicas y composicionales (petrográficas, mineralógicas y químicas) similares que parecen apuntar a la campiña gaditana (especialmente la zona de Jerez de la Frontera, Puerto de Santa María y Espera) como lugar de origen de las arcillas y área de fabricación (Carretero 2007: 48-54). Esta se desarrolló desde finales del s. IV, al menos, hasta finales del III o inicios del II a.C. Su distribución se extiende, como se ha visto, desde el Algarve Oriental hasta el litoral alicantino, a lo que habría que añadir el N de Marruecos (Carretero 2007: 156), concentrándose sobre todo en la costa atlántica del Estrecho y el interior de los valles del Guadalquivir y del Guadalete (García Fernández y García Vargas 2010: 119).

$\mathrm{Al}$ igual que su origen y procedencia, el contenido de estas ánforas se ha determinado en laboratorio, siendo probablemente el aceite el principal producto envasado, como podría desprenderse también de la ausencia de impregnaciones de resina en su interior y el uso sistemático de un engobe blanquecino amarillento en la superficie exterior para reducir la porosidad de la arcilla y aislar la carga (Carretero 2007: 54-55). En efecto, aunque ya se sospechaba por sus características y contextos de hallazgo que podían portar excedentes agropecuarios (González 1987), por ejemplo vino (Ruiz Mata 1995: 192), o incluso preparados piscícolas (Rodero 1991: 289), gracias a los análisis realizados sobre varios ejemplares provenientes tanto de las factorías agrícolas de la campiña de Jerez de la Frontera como de la propia ciudad de Cádiz, se ha podido comprobar que la mayoría de los 
ejemplares estarían destinados seguramente al transporte de aceite de oliva, poco filtrado o sin filtrar (Carretero 2007: 66), o bien de conservas de aceitunas (Tresserras y Matamala 2004: 285).

\section{RAMON T-8.2.1.1}

Por último, un contenedor omnipresente en los contextos urbanos del Bajo Guadalquivir es el ánfora T-8.2.1.1 o tipo Carmona (Rodero 1991). Aunque podría estar relacionado con la forma anterior e igualmente inspirado en prototipos centromediterráneos (Ramón 1995: 225), es un recipiente de cuerpo cilíndrico, boca ancha y fondo apuntado, con el diámetro máximo en el tercio inferior, lo que le otorga su característica silueta ojival. Carente también de hombros y de cuello, sus labios arrancan directamente por encima de las asas, a veces separados por una acanaladura o por un suave escalón, adquiriendo un perfil alargado, más o menos engrosado al exterior y/o al interior, con una proyección vertical o ligeramente exvasada (Ramón 1995: 225). Esta aparente variedad que se observa en sus secciones es un reflejo de la multiplicidad de talleres que debieron fabricar simultáneamente estos envases. No obstante, sí se aprecia una diferencia entre las primeras producciones, con formas más cortas y anchas, y las versiones evolucionadas que a partir del último tercio del s. III a.C. van adoptando morfologías mucho más estilizadas, con un aumento de su longitud y una visible reducción de su diámetro (Sáez 2008: 545-546).

La fabricación de este tipo se iniciaría a principios del s. IV, alcanzando una gran expansión durante los ss. III y II a.C. para terminar a finales de esta centuria o inicios de la siguiente (Sáez 2008: 552). Hasta ahora está constatada su presencia en las áreas industriales de Gadir, especialmente en la isla de San Fernando, apareciendo asociado a las estructuras de combustión documentadas en Torre Alta, Pery Junquera, Sector III Camposoto, Villa Maruja, entre otras (Sáez et al. 2004: 113-119; Sáez 2008: 553-556). Fuera de este ámbito, y a excepción de algunas evidencias procedentes del taller tingitano de Kuass (Kbiri 2007: 77, figs. 40-41), no hay pruebas fehacientes de su producción, si bien las pastas de algunos ejemplares podrían apuntar a otras procedencias, como la campiña de Cádiz, donde estos contenedores aparecen con frecuencia asociados a las ánforas T-8.1.1.2, el Bajo Guadalquivir o incluso la costa de Alicante (Carretero 2004: 427-431). De hecho, el hallazgo de varios ejemplares utilizados como material constructivo en uno de los hornos excavados en los sótanos del Palacio Arzobispal de Sevilla, fechados hacia al s. II a.C. (Mora y Romo 2006: 188), permite plantear la posibilidad de que también se elaboraran en Sevilla en un momento avanzado de su producción (García Fernández y Ferrer 2011: 355 357 , abb. 12). No obstante, y a la espera de los resultados de los análisis arqueométricos efectuados sobre varios fragmentos atípicos con fallos de cocción, las pastas de las formas identificadas remiten insistentemente a la bahía de Cádiz, lo que nos obliga a mantener esta hipótesis en cuarentena.

Su distribución coincide a grandes rasgos con la del ánfora T-8.1.1.2, aunque las T-8.2.1.1 suelen ser siempre más representativas, tanto en cantidad como en distribución geográfica, pues no solo comparecen en los grandes centros urbanos, sino también en algunos establecimientos rurales: la encontramos sobre todo en la bahía de Cádiz y las campiñas de Jerez y El Puerto de Santa María, coincidiendo con su área de producción, pero también en el interior de Turdetania (valles del Guadalquivir y Guadalete), el litoral onubense y el Algarve, llegando incluso al estuario del Tajo; por el E se extiende a lo largo de toda la costa mediterránea hasta Cataluña y el Languedoc, estando presente asimismo, como se ha dicho, en los centros norteafricanos de Lixus y Kuass (Sáez et al. 2004: 119-122).

En este caso no se han realizado análisis de residuos orgánicos que permitan confirmar la mercancía o mercancías que transportaban. Comúnmente se admite que estuvieron destinadas a contener preparados piscícolas (Sáez et al.2004: 113), teniendo en cuenta la morfología de estos recipientes, sobre todo el diámetro de boca, la distribución de sus centros de producción, eminentemente costera, así como algunas de las estampillas registradas en su inmediata sucesora (T-9.1.1.1), donde aparecen representados individuos portando piezas de pescado (probablemente atunes) o introduciéndolas en ánforas de la misma forma, es decir, mostrando "diversos momentos del proceso de fabricación y envasado de las salazones y salsas de pescado" (Frutos y Muñoz 1994: 403-404). Sin embargo, si aceptamos la posibilidad de que se fabricaran también en las factorías agrícolas del interior de la campiña gaditana no podemos descartar otros contenidos, como aceite o quizás vino (Carretero 2004: 417-418). Cabe, por lo tanto, preguntarse si estas ánforas estuvieron orientadas exclusivamente a la comercialización de conservas de pescado o si, por el contrario, nos encontramos ante recipientes polifuncionales y, en este caso, qué mercancías circularon envasadas por los puertos del Bajo Guadalquivir. 
Fig. 2: Ubicación de Alcalá del Río (Ilipa) y Vico (Marchena, Sevilla) en el contexto del poblamiento del Bajo Guadalquivir a finales de la Edad de Hierro.

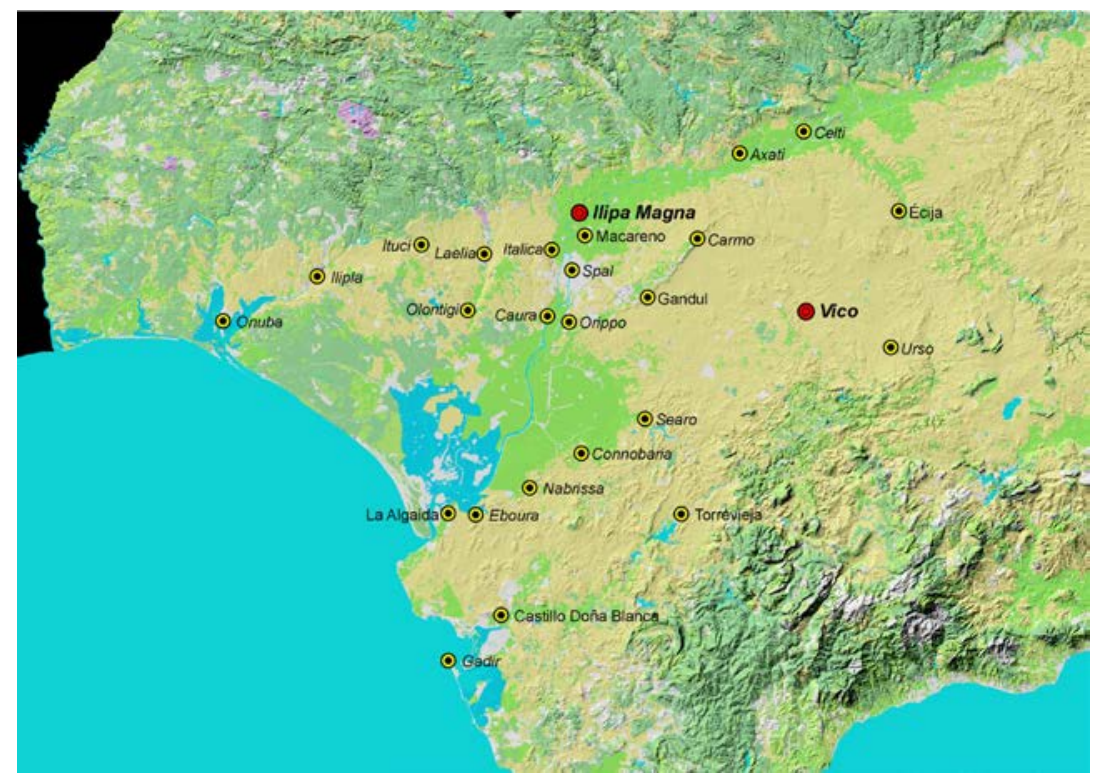

\section{LA MUESTRA ANALIZADA: INDIVIDUOS $\mathrm{Y}$ CONTEXTOS}

Para el análisis de muestras se han elegido fragmentos de ánforas estratificados en los yacimientos de Alcalá del Río (la antigua Ilipa Magna) y Vico (Marchena, Sevi1la), teniendo en cuenta los siguientes criterios (fig. 2):

a) Desde el punto de vista geográfico y funcional, el primero se encuentra a orillas del Guadalquivir, en el último tramo al que podían acceder los barcos de calado medio y en un importante nodo de comunicaciones terrestres-fluviales que hacen de esta localidad un puerto estratégico tanto para la comercialización de los recursos agropecuarios como, muy probablemente también, para el control del metal procedente del vecino distrito minero de Aznalcóllar (Chic 2007: 150-151); mientras que el segundo es un poblado de primer orden situado en el corazón de la campiña de Marchena, junto a la vega del río Corbones, en un territorio de alto potencial agrícola y con una densa colonización agraria, que tiene sus orígenes en los ss. VII-VI a.C. y que continúa, e incluso se extiende, durante la II Edad del Hierro (García Fernández 2005 y 2007; Ferrer y Bandera 2005 y 2007).

b) Los dos yacimientos cuentan con una secuencia estratigráfica completa al menos en sus fases protohistóricas, lo que permite rastrear la producción, uso y/o circulación de recipientes anfóricos desde un punto de vista diacrónico (Bandera y Ferrer 2002; Ferrer y García Fernández 2007). c) Ambos presentan también contextos bien definidos y datados, con un elenco de materiales elocuente en el que las ánforas se encuentran bien representadas tanto desde el punto de vista cuantitativo como cualitativo (Bandera y Ferrer 2002; Ferrer y García Fernández 2007).

\section{ALCALÁ DEL RÍO (SEVILLA)}

De los dos grupos de muestra, el más numeroso procede de Alcalá del Río, concretamente de la excavación de la calle La Cilla, 4-6. Antes de describir las muestras y los contextos de procedencia de éstas, creemos oportuno dedicar unos párrafos introductorios al yacimiento arqueológico. La población actual se sitúa sobre el solar de la antigua Ilipa, una de las ciudades más renombradas de la Bética romana (Str. III, 2, 2; Plin. Nat. III, 11; Liv. XXXV, 1, 11; Ptol. II, 4, 10; Cosmogr. Rav. 314, 17), importancia que le confirió, entre otros factores, su ubicación junto al Guadalquivir (fig. 2), su cercanía a las minas de Sierra Morena y la feracidad de las tierras que la circundaban (Millán 1989; Chic 2007: passim). Según el estado actual de los conocimientos, aunque con antecedentes poblacionales durante el III milenio a.C., parece que el asentamiento estable se inauguró en los ss. VIII-VII a.C. bajo el casco urbano actual, en la zona más elevada, sobre dos montículos delimitados por una pendiente abarrancada que caía sobre el cauce del río Guadalquivir, y por el 
arroyo Caganchas, que separaba el hábitat de la necrópolis protohistórica de La Angorrilla (Fernández Flores y Rodríguez Azogue 2007: 70-71; Fernández Flores et al. 2014).

La documentación de contextos prerromanos en Alcalá del Río es muy reciente, y apenas han sido registrados una decena de ellos, por lo que cualquier dato sobre la extensión, evolución y estructuración del hábitat es necesariamente preliminar. De los sondeos arqueológicos realizados hasta la fecha, el de mayor extensión superficial y del que poseemos más datos se ubica en la calle La Cilla, situada en lo que debió ser una suave pendiente de la zona más elevada (33-35 m s.n.m.) del asentamiento prerromano. La secuencia estratigráfica de este sector es muy compleja, inaugurada a principios del $\mathrm{s}$. VII a.C. y continuada hasta la actualidad, por lo que se haya profundamente alterada por la actividad constructiva de las épocas romana, bajomedieval y contemporánea. La fase más antigua, datada entre los ss. VII e inicios del V a.C., se caracteriza por la construcción de un conjunto de estancias que sirvieron de base para sucesivas fases constructivas, sin que variaran la orientación ni la estructuración del espacio hasta que en los ss. II-I a.C. se produjo una reforma urbanística profunda del sector.

En el período turdetano se han distinguido, por tanto, tres fases, la primera de las cuales se data a fines del s. VI o comienzos del V a.C. en el momento de su amortización, habiéndose localizado exclusivamente en el sector SE de la excavación. Se trata de tres estancias construidas con adobes sobre cimientos de guijarros y suelos de tierra batida teñidos de rojo, en las que se han definido hogares, plataformas y bancos realizados también con adobes. La segunda fase constructiva puede fecharse grosso modo en el s. IV e inicios del III a.C., y se amortiza a fines de esta misma centuria, afectando a la extensión completa de la excavación. Con leves reformas entre una fase y otra, no hay grandes cambios en lo que se refiere a la orientación o a las técnicas constructivas de los edificios. Finalmente, tras un breve período de abandono, a fines del s. III o principios del II a.C. se advierte una tercera fase constructiva que consistió en el realzado de los muros anteriores, por lo que la articulación de los espacios siguió siendo similar a la de fases anteriores. La amortización de esta fase no se conoce bien debido al arrasamiento de las estructuras por la construcción de un gran edificio del período tardorrepublicano.

Se seleccionaron 25 muestras de fondos y bordes de ánforas de cuatro tipos diferentes (T-8.2.1.1, T-8.1.1.2, Pellicer B-C y Pellicer D) hallados en diversos contextos de las fases antedichas (fig. 3, fig. 4-5). Comenzando por la más antigua, se han registrado cuatro bordes de ánforas del tipo Pellicer B-C: el primero fue hallado aislado en el interior de un muro de adobe (UE-317/124), mientras que los otros tres, de un total de cuatro individuos contabilizados, proceden de los niveles de amortización de una de las estancias identificadas, la E-11 (UE-335/9, UE335/11, UE-334/16). Estos últimos contextos están formados por un repertorio cerámico escaso pero significativo desde el punto de vista cronológico, registrándose un vaso evolucionado de boca de seta sin engobe alguno, cerámica hecha a mano y cerámica pintada torneada, con paralelos en los niveles 18 a 16 de Cerro Macareno así como en los niveles A-23 y A-22 de Vico, datados a fines del s. VI o principios del V a.C. (Ferrer y García Fernández 2007: 110).

La segunda fase constructiva está representada por varios contextos que se distribuyen por el área de excavación, comenzando por el suelo 326, donde se documentó un único fondo tipológicamente indeterminado (UE-326/33) entre un conjunto de cerámicas a torno características de los repertorios domésticos de los ss. IV y III a.C.: cuencos de distintos tamaños, platos, urnas, vasos y lebrillos. La amortización del suelo se corresponde con las UE-303, en la que se registró un ejemplar de ánfora T.8.1.1.2 (UE-303/53); la UE 219, también con un borde en este caso de ánfora T-8.2.1.1 (UE-219/32); y, sobre todo, la UE-293, que aportó otros tres bordes del tipo Pellicer D (UE-293/31; UE-293/32; UE-293/33), de un conjunto mínimo de 7 individuos identificados.

De la tercera fase hay varios conjuntos muy representativos de las ánforas que circularon en el antiguo estuario del Guadalquivir en los momentos finales de la Edad del Hierro y los inicios de la presencia romana. En la unidad estratigráfica UE 319 se registraron un total de seis individuos, de los que se seleccionaron dos muestras de fondos: la primera de tipología indeterminada (UE-319/119), aunque probablemente perteneció a un envase tipo Pellicer D, mientras que la segunda puede clasificarse con seguridad en este tipo (UE-319/122). En este mismo contexto, muy pródigo en restos cerámicos, se han distinguido también ánforas Pellicer B-C y T-8.1.1.2 así como abundantes recipientes de cerámica común, con o sin decoración pintada: cuencos, platos, vasos de perfil en $S$, cuencos-lucerna, urnas, urnas con baquetón, lebrillos y un ejemplar vasito globular pintado, con una cronología 


\begin{tabular}{|c|c|c|c|c|c|}
\hline Intervención & UE / Nivel & $\mathbf{N}^{0}$ & Cronología & Fragmento & Tipo \\
\hline ROD-06/7 & 317 & 124 & fines s. VI - inicios s. V & Borde & Pellicer B-C \\
\hline ROD-06/7 & 335 & 9 & fines s. VI - inicios s. V & Borde & Pellicer B-C \\
\hline ROD-06/7 & 335 & 11 & fines s. VI - inicios s. V & Borde & Pellicer B-C \\
\hline ROD-06/7 & 334 & 16 & fines s. VI-inicios s. V & Borde & Pellicer B-C \\
\hline ROD-06/7 & 326 & 33 & s. IV - inicios s. III & Fondo & Indeterminado \\
\hline ROD-06/7 & 303 & 53 & s. IV - inicios s. III & Borde & T-8.1.1.2 \\
\hline ROD-06/7 & 293 & 31 & s. IV - inicios s. III & Borde & Pellicer D \\
\hline ROD-06/7 & 293 & 32 & s. IV - inicios s. III & Borde & Pellicer D \\
\hline ROD-06/7 & 293 & 33 & s. IV - inicios s. III & Borde & Pellicer D \\
\hline ROD-06/7 & 219 & 32 & s. IV - inicios s. III & Borde & T-8.2.1.1 \\
\hline ROD-06/7 & 319 & 119 & $3^{\circ} 1 / 3 \mathrm{~s} . \mathrm{III}$ & Fondo & Pellicer D \\
\hline ROD-06/7 & 319 & 122 & $3^{\circ} 1 / 3$ s. III & Fondo & Pellicer D \\
\hline ROD-06/7 & 329 & 36 & fines s. III & Borde & T-8.2.1.1 \\
\hline ROD-06/7 & 329 & 37 & fines s. III & Borde & T-8.1.1.2 \\
\hline ROD-06/7 & 226 & 118 & fines s. III & Borde & $\mathrm{T}-8.2 .1 .1$ \\
\hline ROD-06/7 & 226 & 123 & fines s. IIl & Borde & $T-8.2 .1 .1$ \\
\hline ROD-06/7 & 226 & 124 & fines s. III & Borde & Pellicer D \\
\hline ROD-06/7 & 226 & 125 & fines s. III & Fondo & $\mathrm{T}-8.2 .1 .1$ \\
\hline ROD-06/7 & 226 & 126 & fines s. III & Borde & Pellicer B-C \\
\hline ROD-06/7 & 226 & 128 & fines s. III & Borde & $\mathrm{T}-12.1 .1 .1$ \\
\hline ROD-06/7 & 236 & 33 & fines s. III - inicios s. II & Borde & Pellicer D \\
\hline ROD-06/7 & 298 & 138 & $2^{\mathrm{a}} 1 / 2 \mathrm{~s} . \mathrm{II}$ & Borde & T-8.2.1.1 \\
\hline ROD-06/7 & 298 & 139 & $2^{a} 1 / 2$ s. II & Fondo & T-8.2.1.1 o T-8.1.1.2 \\
\hline ROD-06/7 & 298 & 141 & $2^{\mathrm{a}} 1 / 2 \mathrm{s.} \mathrm{II}$ & Fondo & $\mathrm{T}-8.2 .1 .1 \circ \mathrm{T}-8.1 .1 .2$ \\
\hline ROD-06/7 & 298 & 143 & $2^{\mathrm{a}} 1 / 2 \mathrm{s.} \mathrm{II}$ & Borde & T-8.1.1.2 \\
\hline VICO-85 & A- 22 & 33 & fines s. VI - inicios s. V & Fondo & Pellicer B-C (?) \\
\hline VICO-85 & A-19 sur & 20 & s. V & Fondo & Pellicer B-C (?) \\
\hline VICO-85 & A-16 & 12 & $\mathrm{I}^{\mathrm{a}} \mathrm{I} / 2 \mathrm{~s} . \mathrm{IV}$ & Fondo & Pellicer B-C (?) \\
\hline VICO-85 & A-9 & 24 & $2^{\mathrm{a}} 1 / 2$ s. III & Fondo & Pellicer D (?) \\
\hline VICO-85 & A-7 & 35 & $3^{\circ} 1 / 3 \mathrm{s.} \mathrm{III}$ & Fondo & Pellicer D \\
\hline VICO-85 & A-7 & 36 & $3^{\circ} 1 / 3 \mathrm{~s} .1 \mathrm{II}$ & Fondo & Pellicer D \\
\hline
\end{tabular}

Fig. 3: Relación de muestras de ánforas procedentes de Alcalá del Río y Vico.

atribuible al último tercio del s. III a.C. Otras dos muestras, en este caso de los tipos T-8.1.1.2 (UE329/37) y T-8.2.1.1 (UE-329/36), fueron registradas en la UE 329. El repertorio cerámico de este contexto presenta una composición similar al anterior: urnas pintadas con o sin baquetón, vasos de perfil en S, lebrillos, ollas de cocina, platos y cuencos pintados, con una datación cercana a la segunda Guerra Púnica.

Asociada a esta última se encuentra la UE-226, una de las más mejor representadas en número de recipientes anfóricos identificados (un total de 6): un fondo de T-8.2.1.1 (UE-226/125), dos bordes del mismo tipo (UE-226/118 y
UE-226/123), sendos bordes de ánforas Pellicer B/C (UE226/126) y Pellicer D (UE-226/124), además de un raro fragmento de T-12.1.1.1 con un grafito fenicio en forma de aspa o tau (UE 226/128). El resto del abundantísimo material cerámico está formado por un repertorio característico de la segunda mitad, o mejor, de fines del s. III: platos y cuencos pintados, urnas, lebrillos, vasos de perfil en $\mathrm{S}$, cuencos-lucerna y ollas de cocina. Similares materiales encontramos en la UE-236, cuya cronología podría adentrarse ya en los primeros compases del s. II a.C. La muestra obtenida de esta unidad, con un número mínimo de cinco individuos, consiste en un borde de Pellicer D 
Francisco José García Fernández, Eduardo Ferrer Albelda, Paloma Álvarez Mateos, María Montaña Durán Barrantes

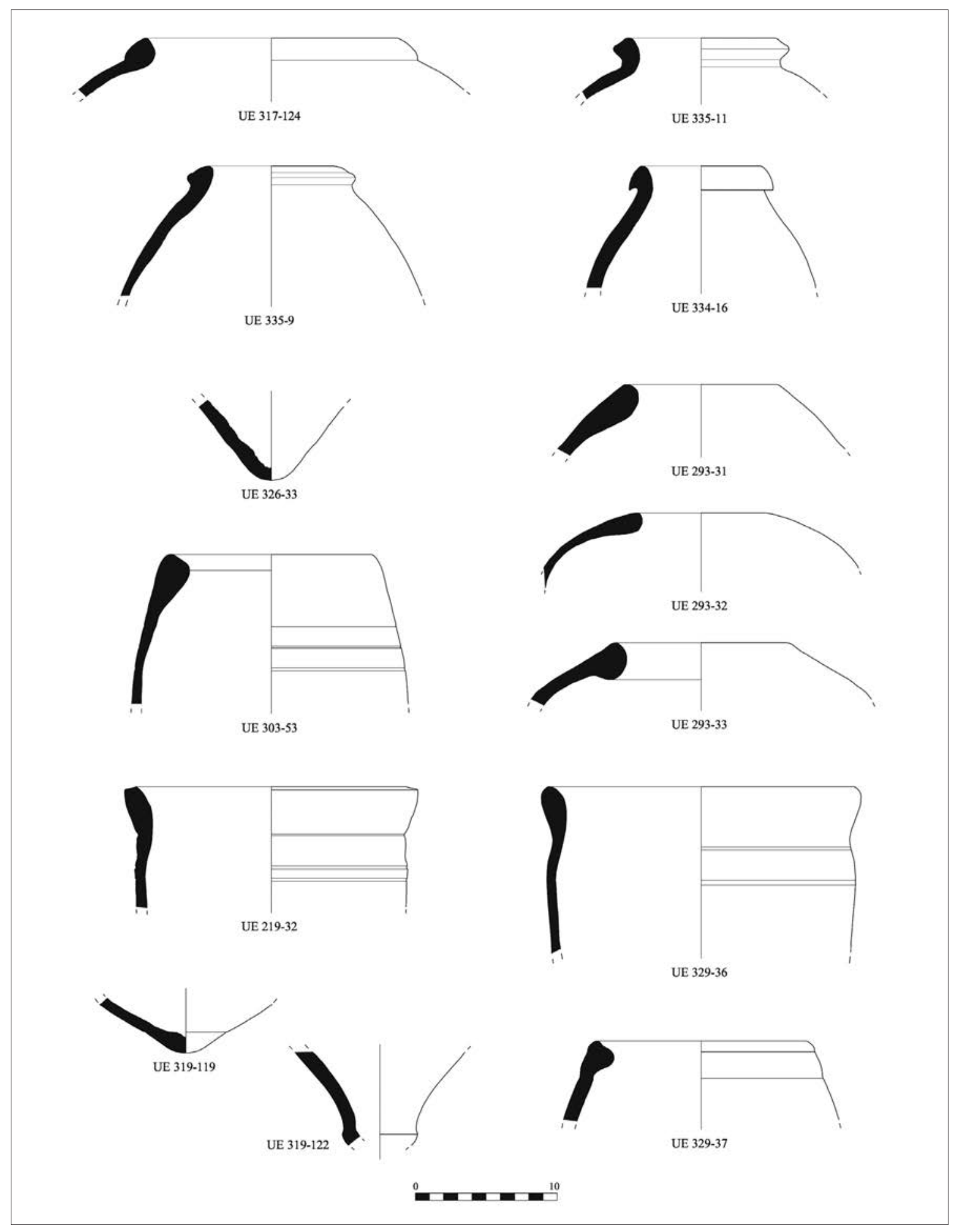

Fig. 4: Representación de los fragmentos procedentes de Alcalá del Río.

68 
(UE-236/33), que comparece junto con otros ejemplares del mismo tipo y del T-8.2.1.1, cuencos y urnas pintadas, lebrillos, ollas de cocina, así como las primeras evidencias de vajilla tipo Kouass (Ferrer y García Fernández 2007: 117, fig. 12).

El contexto más reciente es el formado por la UE298, de la que se seleccionaron dos fondos de ánforas T-8.2.2.1 (UE-298/139 y UE-298/141), un borde del mismo envase (UE-298/138) y otro del tipo T-8.1.1.2 (UE-298/143), entre un total de ocho individuos. Esta unidad estratigráfica contenía una gran cantidad de fragmentos cerámicos entre los que se contabilizaron ya restos de vajilla campaniense y un ánfora grecoitálica, junto con un mortero, platos y cuencos con decoración pintada en rojo, cuencos-lucerna, cuencos de perfil en $\mathrm{S}$, urnas, lebrillos, ollas de cocina, cerámica decorada con ondas y un vasito globular pintado a bandas, un repertorio característico de mediados del s. II a.C.

\section{VICO (MARCHENA, SEVILLA)}

Por su parte, el yacimiento de Vico es un asentamiento prototípico de la campiña sevillana (fig. 2). A orillas del río Corbones, uno de los afluentes más importantes del Baetis por su margen izquierda, constituye un tell que formaba, junto con Montemolín, un único hábitat (Bandera et al. 1993 y 1995), erigido durante gran parte del I milenio a.C. como centro de un territorio dependiente probablemente de Carmo (Carmona, Sevilla), la principal entidad política regional (Ferrer et al. 2011: 89). Las excavaciones arqueológicas llevadas a cabo en los dos cerros han permitido conocer la función de ambos sectores: Montemolín durante el Bronce Final y el Hierro I (ss. IX-VI a.C.) funcionó como acrópolis, acogiendo un conjunto de edificios singulares destinados a la reunión de las élites y al sacrificio y consumo de animales domésticos (Chaves y Bandera 1991; Bandera y Ferrer 1998; Bandera et al. 1999; Chaves et al. 2000; Ferrer y Bandera 2007), mientras que Vico, en una situación orográfica menos prominente, en la falda del cerro y próximo al río, fue el hábitat propiamente dicho, al menos desde el s. VII a.C., que es la datación del nivel de habitación más antiguo documentado en el sondeo estratigráfico, sin que la secuencia estuviese agotada (Bandera y Ferrer 2002).

Los estudios territoriales de este sector de la campiña han permitido establecer cómo, a partir del s. VII a.C., se generó un patrón de asentamiento caracterizado por una acusada jerarquización de los hábitats, clasificados en cuatro categorías: oppida o lugares centrales, entre los que se encuentran Montemolín-Vico, asentamientos tipo torre o atalaya, aldeas y granjas, estos dos últimos exponentes de un fenómeno que hemos denominado "colonización agraria" (Ferrer y Bandera 2005; Ferrer et al. 2007). Esta ordenación del territorio perduró sin apenas modificaciones hasta la romanización, ya cercana al cambio de era (Ferrer y Bandera 2007; García Fernández 2005 y 2007), cuando algunos de estos oppida decayeron o fueron abandonados.

Centrados en el poblado de Vico, las actuaciones arqueológicas se han limitado hasta la fecha a dos intervenciones distintas entre sí y alejadas en el tiempo: en 1985 se realizó un sondeo estratigráfico (A) en la parte superior del cerro, de $3 \times 3 \mathrm{~m}$, que proporcionó una estratigrafía cercana a los $6 \mathrm{~m}$ y una secuencia de habitación ininterrumpida -sin llegar a los niveles no antropizados-desde el s. VII a.C. hasta las fases de ocupación romana, ya muy alterados por la erosión (Chaves y Bandera 1987: 372-379; Bandera y Ferrer 2002: passim); mientras que en 2007 se programó la actuación más reciente, una prospección geofísica (detección magnética) mediante la cual se ha conseguido generar una imagen de las estructuras conservadas en el subsuelo que sugieren una urbanización del lugar siguiendo un plano ortogonal, con ejes de circulación (calles) y conjuntos de construcciones, presumiblemente del s. III a.C. (Chaves et al., e.p.).

De los restos de ánforas registrados en la excavación de 1985 se han seleccionado exclusivamente fondos porque, siendo menos diagnosticables, tienden a retener más restos orgánicos que los bordes, lo cual se ha demostrado válido en este caso, pues las seis muestras han aportado resultados positivos. De más antigua, desde el punto de vista estratigráfico, a la más reciente, las muestras seleccionadas son Vi-85/A-22/33, Vi-85/A-19 sur/20, Vi85/A-16/12, Vi-85/A-9/24, Vi-85/A-7/35 y Vi-85/A-7/36 (fig. 3, fig. 5).

La muestra Vi-85/A-22/33 se documentó en el nivel 22 (estrato XI), datado a fines del s. VI o principios del V a.C. por comparación estratigráfica (niveles 18 a 16 de Cerro Macareno: Pellicer et al. 1983; Bandera y Ferrer 2002: 131) y por criterios tipológicos del repertorio cerámico, compuesto por formas evolucionadas de las cerámicas del Hierro I, como pithoi y urnas tipo Cruz del Negro, platos y urnas con decoración monócroma o bícroma, ollas de cocina, un asa y otros dos bordes de ánfora Pellicer B-C (NMI = 2). La muestra procede del fondo de una de estas ánforas Pellicer B-C y el contexto donde 
Francisco José García Fernández, Eduardo Ferrer Albelda, Paloma Álvarez Mateos, María Montaña Durán Barrantes

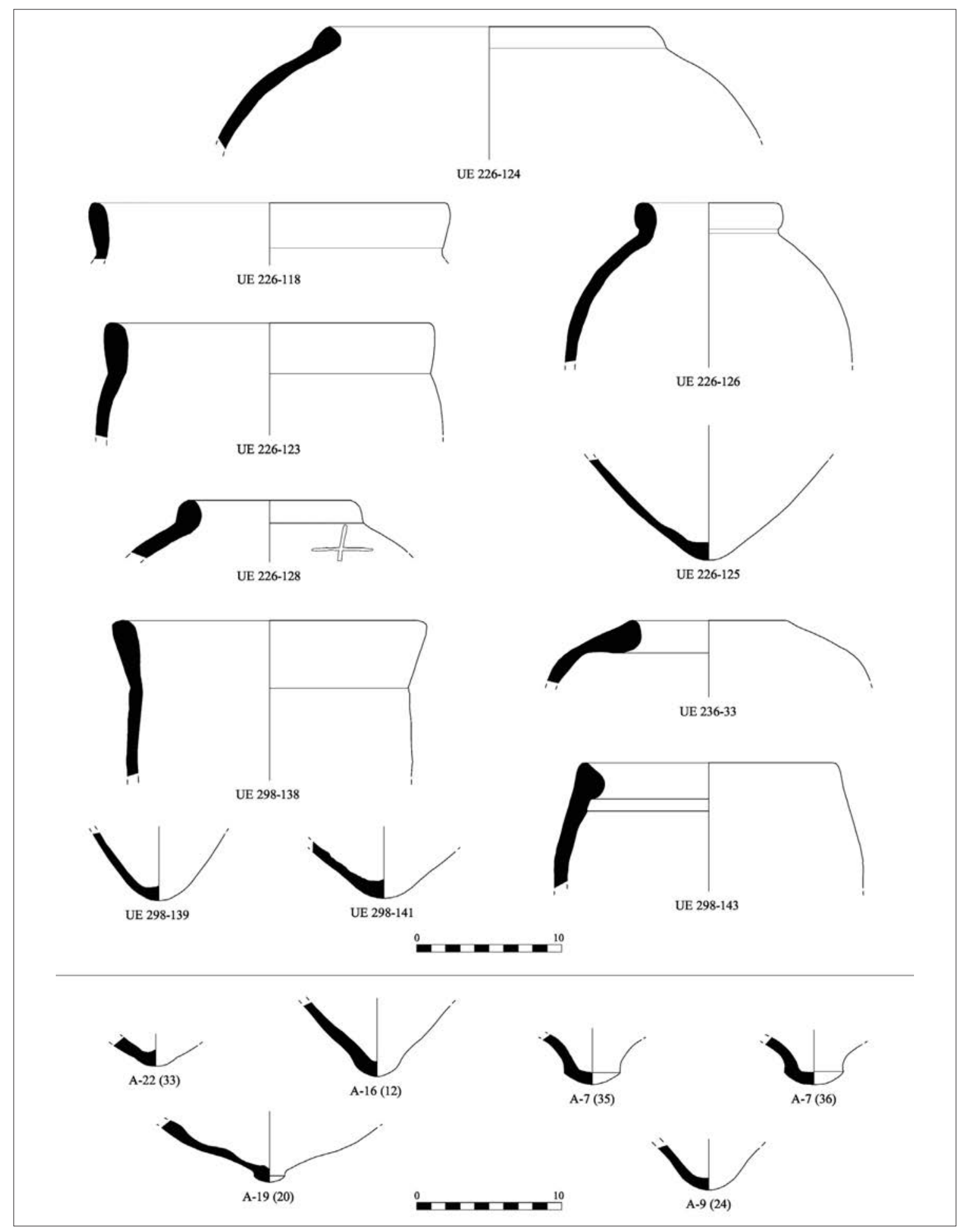

Fig. 5: Representación de los fragmentos procedentes de Alcalá del Río (arriba) y Vico (abajo). 
se halló es un estrato que cubre otro (nivel A-23a, estrato $\mathrm{X}$ ) depositado a su vez sobre un suelo (nivel 23b, estrato IX). Su composición sugiere una formación por actividades domésticas y acumulación de basuras (restos óseos de animales, caracoles, cenizas y tierra quemada, restos de adobes y muchos fragmentos de recipientes cerámi$\cos )$. En este contexto se halló también un fragmento de ánfora atípico con un grafito representando la letra šin fenicia (Bandera y Ferrer 2002: 135, fig. 11: 9), idéntico a otros registrados sobre ánforas Pellicer B-C en Carmona, de fines del s. VI a mediados del V a.C. (Belén et al. 1997: 84, fig. 9: 1), en Cerro Macareno (Fernández et al. 1979: 72 y 74, fig. 4; Ruiz Cabrero y Mederos 2002: $97-$ 98), uno de los cuales se grabó ante coctionem sobre un borde del mismo tipo (Fernández et al. 1979: 71, fig. 42), y en otros puntos del Mediterráneo occidental con cronologías que oscilan entre los ss. V a.C. y I d.C. En este sentido, resulta interesante la idea de que estas marcas de alfar pudieran indicar el contenido del ánfora, sobre todo teniendo en cuenta el paralelo próximo oriental de Tell Miqne-Ekron (s. VII a.C.), donde los grafitos con la letra š parecen hacer alusión al aceite ( $\breve{s} m n$ ), como se desprende de los catorce ejemplares que portaban esta marca hallados en un almacén al S del Temple-Complex X (Ruiz Cabrero y Mederos 2002: 112-113).

El contexto arqueológico de la muestra Vi-85/A-19 sur/20 es un nivel de uso de un suelo apisonado (nivel A$19 b$, estrato XIII) sobre el que se depositaron numerosos fragmentos de recipientes cerámicos, tierra quemada, cenizas, carbones y piedras sueltas (nivel A-19a, estrato XIV), sellado por otro suelo de adobes muy cuidado y de gran dureza (nivel A-18b, estrato XV) (Bandera y Ferrer 2002: 126). El repertorio cerámico que acompaña a la muestra se data en el s. V a.C. por criterios estratigráficos y tipológicos: son característicos los grandes vasos carenados pintados, herederos de los pithoi del Hierro I, las urnas y cuencos pintados, tres asas de ánfora $(\mathrm{NMI}=2)$ y las ollas de cocina, con concomitancias con el registro cerámico de los estratos I y II del corte BI del Cerro de la Cabeza (Domínguez et al. 1988: láms. I-VII; Bandera y Ferrer 2002: 131).

La muestra Vi-85/A-16/12, la única diagnosticable de este nivel, procede de una unidad sedimentaria (nivel A-16, estrato XIX) que amortiza un edificio (muro 5), compuesta por tierra de coloración rojiza, piedras sueltas, carbones, arena y muchos fragmentos de envases cerámicos. La datación relativa atribuida a este contexto, según la estratigrafía comparada (niveles 14 a 12 de Cerro Macareno: Pellicer y otros 1983) y la cronotipología de la cerámica hacen proponer un arco temporal entre 400 y 350 a.C. Junto al fondo de ánfora, han sido descritos grandes recipientes carenados pintados con asas geminadas, evolucionados de los pithoi del Hierro I, platos y cuencos pintados y ollitas de cocina.

El nivel A-9 (estrato XXVI) ofreció también un único fragmento de forma anfórica, correspondiente de nuevo a un fondo (Vi-85/A-9/24). La muestra apareció una unidad sedimentaria cubriendo un suelo de guijarros y arena de gran potencia que ocupaba gran parte de la superficie del sondeo. La datación, según los criterios antedichos, se centra ya en la segunda mitad del s. III a.C. El resto del repertorio cerámico descrito en este estrato consiste en cuencos, cuencos-lucerna, urnas pintadas o sin decoración con el labio biselado en el exterior y ollas de cocina.

Las muestras Vi-85/A-7/35 y Vi-85/A-7/36 se hallaron, junto con un borde de ánfora Pellicer $\mathrm{D}(\mathrm{NMI}=2)$, en el nivel A-7 (estrato XXVII). Se trata nuevamente de un estrato de formación antrópica, quizás de derrumbe y relleno, con abundantes restos óseos, carbones, adobes y fragmentos cerámicos, sobre todo de ánforas. La cronología de este nivel, dado que la unidad sedimentaria que lo cubre se corresponde con la última fase de habitación de Montemolín y con la segunda Guerra Púnica, debe atribuirse a unas fechas inmediatamente anteriores a la conflagración, en el último tercio del s. III a.C. Son muy característicos en esta época los "anforiscos", pequeños vasos con decoración pintada hasta ahora documentados en Montemolín, Cerro Naranja y Alhonoz (Ferrer y García Fernández 2008: 211), los cuencos pintados con el borde biselado al exterior y al interior (García Vargas et al. 1989: 223-224), a lo que hay que añadir cuencos-lucerna, recipientes de perfil en S, urnas pintadas, ollas de cocina y una ollita con el borde ranurado de probable fabricación gadirita (tipo GDR 12.4.1.), datada entre la segunda mitad del s. III y la primera del II a.C. (Sáez Romero 2005: 165, fig. 3).

\section{METODOLOGÍA}

Con frecuencia, las matrices minerales con las que se han elaborado los recipientes cerámicos ofrecen entornos idóneos para proteger las moléculas orgánicas de la degradación microbiológica. Se presume que las moléculas orgánicas se encuentran, por una parte, contenidas dentro de los espacios formados por los poros, inaccesibles a las enzimas exocelulares producidas por microbios degradantes; y por otra, protegidas debido a la adsorción en 


\begin{tabular}{|l|l|}
\hline \multicolumn{2}{|l|}{ Ácidos Grasos Saturados } \\
\hline C14:0 ácido mirístico & $\mathrm{CH}_{3}\left(\mathrm{CH}_{2}\right)_{12} \mathrm{COOH}$ \\
\hline C16:0 ácido palmítico & $\mathrm{CH}_{3}\left(\mathrm{CH}_{2}\right)_{14} \mathrm{COOH}$ \\
\hline C17:0 ácido margárico & $\mathrm{CH}_{3}\left(\mathrm{CH}_{2}\right)_{15} \mathrm{COOH}$ \\
\hline C18:0 ácido esteárico & $\mathrm{CH}_{3}\left(\mathrm{CH}_{2}\right)_{16} \mathrm{COOH}$ \\
\hline $\mathrm{C} 20: 0$ ácido araquídico & $\mathrm{CH}_{3}\left(\mathrm{CH}_{2}\right)_{18} \mathrm{COOH}$ \\
\hline C22:0 ácido behénico & $\mathrm{CH}_{3}\left(\mathrm{CH}_{2}\right)_{20} \mathrm{COOH}$ \\
\hline Ácidos Grasos Insaturados \\
\hline C16:1 ácido palmitoleico & $\mathrm{CH}_{3}\left(\mathrm{CH}_{2}\right)_{5} \mathrm{CH}=\mathrm{CH}\left(\mathrm{CH}_{2}\right)_{7} \mathrm{COOH}$ \\
\hline C17:1 ácido margaroleico & $\mathrm{CH}_{3}\left(\mathrm{CH}_{2}\right)_{6} \mathrm{CH}=\mathrm{CH}\left(\mathrm{CH}_{2}\right)_{7} \mathrm{COOH}$ \\
\hline $\mathrm{C} 18: 1$ ácido oleico & $\mathrm{CH}_{3}\left(\mathrm{CH}_{2}\right)_{7} \mathrm{CH}=\mathrm{CH}\left(\mathrm{CH}_{2}\right)_{7} \mathrm{COOH}$ \\
\hline $\mathrm{C} 18: 2$ ácido linoleico & $\mathrm{CH}_{3}\left(\mathrm{CH}_{2}\right)_{4} \mathrm{CH}=\mathrm{CHCH} 2 \mathrm{CH}=\mathrm{CH}\left(\mathrm{CH}_{2}\right)_{7} \mathrm{COOH}$ \\
\hline C18:3 ácido linolénico & $\mathrm{CH}_{3} \mathrm{CH}_{2} \mathrm{CH}=\mathrm{CHCH} \mathrm{CH}_{2} \mathrm{CHCH}{ }_{2} \mathrm{CH}=\mathrm{CH}\left(\mathrm{CH}_{2}\right)_{7} \mathrm{COOH}$ \\
\hline $\mathrm{C} 20: 1$ ácido gadoleico & $\mathrm{CH}_{3}\left(\mathrm{CH}_{2}\right)_{9} \mathrm{CH}=\mathrm{CH}\left(\mathrm{CH}_{2}\right)_{7} \mathrm{COOH}$ \\
\hline
\end{tabular}

Fig. 6: Relación de ácidos grasos más comunes en las grasas alimenticias (a partir de Fennema 2000). superficies de lípidos, sustancias difíciles de degradar por microorganismos. Esta protección también puede ser debida al atrapamiento dentro de matrices orgánicas, como los residuos orgánicos carbonizados (Regert et al. 1998). En este caso, nos centraremos en la caracterización de ácidos grasos (AGs) y su identificación con productos concretos, tanto alimentos como sustancias conservantes o condimentos. No olvidemos que la composición típica de los distintos aceites de origen vegetal y animal tiene una serie común a todos ellos, pero con concentraciones distintas que permiten la agrupación de unos y otros según predominen los AGs de carácter saturado, monoinsaturado o poliinsaturados.

Se conoce con el nombre genérico de lípidos el conjunto de moléculas presentes en las grasas tanto de origen animal como vegetal, una parte muy importante de la dieta humana. Su propiedad química principal es su carácter hidrófobo, lo que favorece su permanencia en el lugar en que fueron depositados, y, por lo mismo, ser solubles en disolventes orgánicos, lo cual facilita su extracción selectiva en el laboratorio cuando, como en este caso, han sido contenidos en recipientes cerámicos. Los lípidos de mayor interés en el campo de la investigación arqueológica son los ácidos grasos, la mayoría de carácter monocarboxílico de cadena lineal, distinguiéndose unos de otros en la longitud de la cadena y en el grado de insaturación, es decir, en la presencia y número de dobles enlaces, predominantemente con un número par de átomos de carbono, entre 4 y 30, aunque ácidos grasos con más de 20 átomos de carbono no son frecuentes en la naturaleza. Así pues, denominamos ácidos grasos monoinsaturados a aquellos que cuentan con un doble enlace en la cadena hidrocarbonada y poliinsaturados a los de más de un doble enlace (fig. 6).
El grado de conservación de los componentes grasos de los alimentos, cuando están contenidos en un recipiente cerámico, se encuentra determinado por los procesos postdeposicionales que suceden a la amortización del recipiente, así como a las condiciones y características del estrato que lo alberga. A pesar de que los lípidos tienden a quedar atrapados en la matriz arcillosa y pueden permanecer protegidos de agresiones degradativas externas (Heron et al. 1991), también es cierto que cualquier cambio en el ambiente de deposición puede ser muy negativo para la muestra. Más allá de la propia alteración física del recipiente, que provoca su fractura y dispersión, hay que considerar los distintos cambios químicos que se pueden sucederse: la hidrólisis, provocada por la humedad, temperatura, enzimas y microorganismos, produciendo la liberación de los ácidos grasos que forman parte de los acilgliceroles (molécula de glicerol con 1, 2 ó 3 moléculas de ácidos grasos esterificadas); la oxidación, principalmente de las moléculas de ácidos grasos insaturados con más de un doble enlace y no tanto en los de un solo doble enlace (ácido oleico) (Evershed et al. 1992); la degradación microbiológica, en condiciones aeróbicas, que daría muchos tipos de transformaciones químicas; y la contaminación lipídica post-excavación, debido al almacenamiento de las muestras en plásticos (por los ftalatos de este último) o al contacto con los lípidos de la piel humana. Por último, hay que contemplar la posibilidad de que los recipientes cerámicos, incluso los destinados al transporte como es el caso de las ánforas, se reutilizaran para contener distintos alimentos, lo que queda patente cuando se da la presencia simultánea de compuestos exclusivos de ciertas especies animales o vegetales. 
Fig. 7: Porcentaje de los distintos tipos de ácidos grasos presentes en los diferentes aceites y grasas (adaptado de Surra et al. 2005, con permiso de Sociedad Española de Obesidad). SAT: \% ácidos grasos saturados; AGMI: \% ácidos grasos monoinsaturados; AGPI: \% ácido grasos poliinsaturados

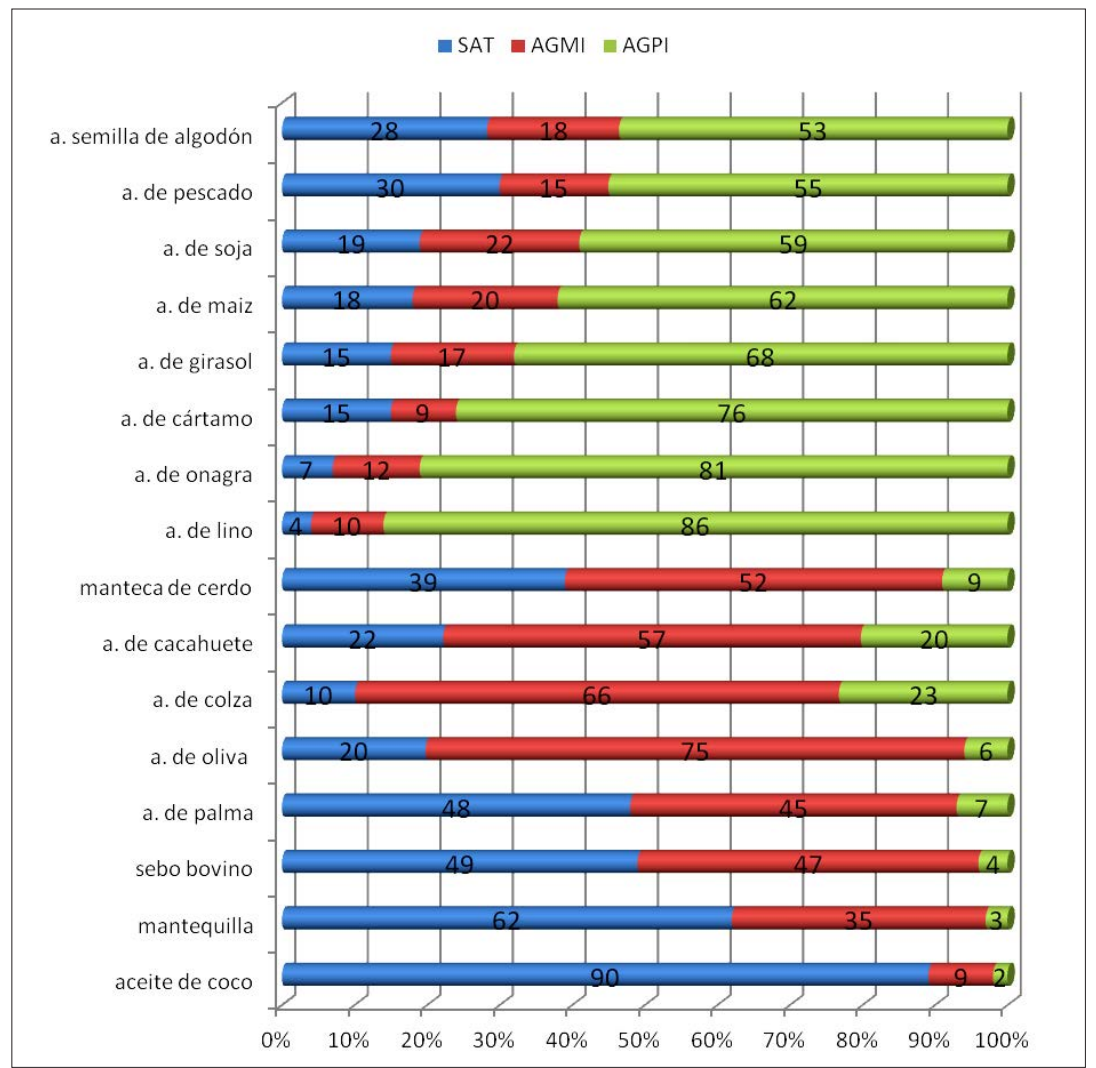

Es difícil encontrar datos bibliográficos al respecto pues la única forma de conocer estas condiciones es simularlas en el laboratorio, con variaciones de los distintos parámetros entre los cuales el factor tiempo, en un material enterrado, es definitivo e irrepetible. Es por ello que las posibles deducciones respecto a los valores analíticos son, efectivamente, deducciones y nunca resultan concluyentes para con el contenido alimentario que se encontrara en origen en las ánforas, debiéndose apoyar dicho estudio en el contexto socio-cultural del registro arqueológico (Evershed et al. 2002).

\section{EL CONTENIDO EN ÁCIDOS GRASOS EN LOS ALIMENTOS}

Una herramienta útil para clasificar los aceites degradados incluye el análisis de la relación de ciertos ácidos grasos "llave". Esta información puede ayudar a distinguir entre grasas animales y vegetales, y en algunos casos puede estrechar el abanico de posibilidades entre clases específicas de animales y vegetales. Existen referencias bibliográficas que evidencian agrupaciones típicas que permiten diferenciar grasas de origen vegetal, verduras y semillas, pescados, mamíferos terrestres y, en este último caso, entre animales herbívoros y carnívoros (Eerkens 2005; Izquierdo et al. 2000). Pero en aceites vegetales la dificultad es mucho mayor debido a la inestabilidad molecular ligada al alto grado de instauración de estas grasas líquidas. La caracterización de un alimento concreto es posible con el estudio de dichos ácidos, tanto de forma individual como a partir de la agrupación de unos u otros según su carácter molecular saturado, monoinsaturado o poliinsaturado (fig. 7, fig. 8).

Si se quiere llegar a determinar un tipo concreto de aceite, se podría hacer considerando las proporciones típicas de los distintos AGs dentro de un margen, y en cada uno de dichos caracteres saturados, mono y poliinsatuados. Pero además, existe una serie de componentes minoritarios en los aceites vegetales cuya naturaleza y proporción es característica en cada uno de ellos y, por lo tanto, facilitan la tarea de diferenciar químicamente unos de otros. En el caso del aceite de 


\begin{tabular}{|l|c|c|c|c|}
\hline $\begin{array}{l}\text { Tipo de ácido } \\
\text { grado }\end{array}$ & $\begin{array}{c}\text { Aceite de } \\
\text { oliva }\end{array}$ & $\begin{array}{c}\text { Aceite de } \\
\text { peseado }\end{array}$ & Manteca & $\begin{array}{c}\text { Sebo } \\
\text { vacuno }\end{array}$ \\
\hline Butanoico (C4:0) & - & - & 10 & - \\
\hline Palmítico (C16:0) & 5 & 20 & 25 & 35 \\
\hline Esteárico (C18:0) & 5 & 5 & 15 & 35 \\
\hline Oleico (C18:1) & 85 & 25 & 30 & 25 \\
\hline Otros (AGPI) & 5 & 50 & 20 & 5 \\
\hline
\end{tabular}

\begin{tabular}{|l|c|}
\hline Tipo de ácido graso & Aceite de oliva (porcentaje) \\
\hline Mirístico (C14:0) & $0.0-0.05$ \\
\hline Palmítico (C16:0) & $7.5-20$ \\
\hline Palmitoleico (C16:1) & $0.3-3.5$ \\
\hline Margárico (C17:0) & $0-0.3$ \\
\hline Heptadecenoico (C17:1) & $0-0.3$ \\
\hline Esteárico (C18:0) & $0.5-5$ \\
\hline Oleico (C18:1) & $55-83$ \\
\hline Linoleico (C18:2) & $3.5-21$ \\
\hline Araquídico (C20:0) & $0-0.6$ \\
\hline Eicosenoico (C20:1) & $0-0.4$ \\
\hline Behénico (C22:0) & $0-0.2$ \\
\hline Lignocérico (C24:0) & $0-0.2$ \\
\hline
\end{tabular}

Fig. 8: Composición de grasas comestibles tradicionales en la alimentación humana (\%) (López Sabater et al. 1985). Porcentaje de los diferentes ácidos grasos presentes en el aceite de oliva (a partir de Boskou 1996; Montedoro et al. 2007.

oliva, la concentración predominante de ácido oleico, ácido graso monoinsaturado, así como la presencia del hidrocarburo escualeno (linealmente, supone una molécula $\mathrm{C}_{30} \mathrm{H}_{50}$ con seis dobles enlaces no conjugados), serán los que definan su perfil típico cromatográfico (fig. 8) entre otros aceites vegetales como el de palma (ácidos grasos de cadena corta y saturados, principalmente), el de semilla (mayor grado de insaturación molecular), o el aceite de origen animal (predominan las grasas saturadas, principalmente de cadena corta en aceites de pescado, y de cadena media y larga en el de animales, como el cerdo o la ternera). El escualeno, molécula con un importante papel en la estabilidad frente a las autooxidaciones, suele presentarse en el aceite de oliva virgen en una concentración de 150800 mg/100g (Montedoro et al. 2007; Jiménez et al. 2001 ), lo que supone entre un $0.2-0.7 \%$ del total, frente a las que contienen otros aceites vegetales, que no superan el $0.13 \%$. También se encuentra en aceites de pescado (Smith et al. 1998; Newmark 1999), aunque estos últimos cuentan con menor proporción de ácido oleico respecto del aceite de oliva, así como una distribución distinta de AGs.

\section{TOMA DE MUESTRAS}

Como ya se ha dicho, para la realización de este trabajo se tomaron un total de 31 muestras de distintos tipos de ánforas que se produjeron y/o distribuyeron por el valle del Guadalquivir durante la II Edad del Hierro: 25 de ellas (19 bordes y seis fondos) proceden del enclave portuario de Alcalá del Río, mientras que las seis restantes (en este caso solo fondos) corresponden al poblado de Vico, en el interior de la campiña.

Debido a la distinta cantidad de restos de materia grasa que se conserva en los bordes en relación con los fondos de los recipientes, se ha hecho un estudio cromatográfico más amplio a estos últimos, así como de un reducido conjunto de bordes que sirva de muestra comparativa entre el contenido de ambas partes. El resto de los bordes ha recibido un tratamiento por separado menos exhaustivo. La única excepción es la muestra UE-326/33, donde se obtuvo un perfil cromatográfico con picos de menor intensidad que en el resto de fondos, por lo que tampoco está incluido en los gráficos correspondientes a este grupo. Cuando los fragmentos de ánforas son mayores, se ha optado por realizar el estudio analítico por duplicado, al haber más cantidad de muestra cerámica. Este fue el caso de los fondos UE-319/122 y UE-329/37. Igualmente el borde UE-335/11 se analizó por duplicado pero, conociendo que su contenido en grasa no sería significativo, se utilizó para añadirle una gota de aceite de oliva virgen con el fin de que represente el dato cromatográfico de referencia de aceite en un fragmento de ánfora. Adicionalmente, se ha analizado cromatográficamente una muestra del mismo aceite de oliva virgen, en estado líquido, sin contacto con material alguno, y se recoge en la figura 9 correspondiente a una selección de fondos y bordes.

\section{DESCRIPCIÓN DEL MÉTODO}

METILACIÓN POR CALENTAMIENTO CON METILATO DE SODIO EN METANOL SEGUIDA DE CALENTAMIENTO EN MEDIO ÁCIDO (IUPAC 1992a y 1992b).

Antes de la determinación cromatográfica de los AGs, se realiza un paso previo consistente en una transesterificación en medio básico con metóxido de sodio, seguida de una esterificación en medio ácido para transformar los ácidos libres que puedan existir en ésteres de alquilo. En primer lugar se tritura la muestra con un 


\begin{tabular}{|l|l|c|c|c|c|c|c|c|c|c|c|c|c|c|c|}
\hline Muestras & Forma & C16:0 & C16:1 & C17:0 & C17:1 & C18:0 & C18:1 & C18:2 & C18:3 & C20:0 & C20:1 & C22:0 & Escualeno & $\begin{array}{c}\text { C16:0/ } \\
\text { C18:1 }\end{array}$ & $\begin{array}{c}\text { AGI/ } \\
\text { AGS }\end{array}$ \\
\hline UE-319/122 & Fondo & 22.03 & 7.31 & 4.79 & 17.92 & 10.74 & 12.70 & 3.87 & 5.95 & 10.01 & 0.00 & 4.68 & 5.26 & 0.58 & 0,91 \\
\hline UE-319/119 & Fondo & 43.77 & - & - & - & 9.90 & 6.53 & - & 25.94 & - & - & 13.84 & 19.59 & 0.15 & 0,48 \\
\hline UE-226/125 & Fondo & 10.47 & - & - & - & 15.14 & - & - & 42.77 & - & - & 31.61 & 1.82 & 0.00 & 0.75 \\
\hline UE-298/141 & Fondo & 40.20 & - & - & - & 10.42 & 15.90 & - & 12.19 & 4.60 & - & 16.67 & 40.11 & 0.40 & 0,39 \\
\hline UE-298/139 & Fondo & 26.29 & 3.15 & - & 3.59 & 11.88 & 3.65 & 2.28 & 29.82 & 2.60 & - & 16.70 & 19.68 & 0.14 & 0,74 \\
\hline UE-329/37 & Borde & 5.40 & 7.31 & 5.89 & 5.94 & 32.39 & 5.54 & 4.64 & 14.53 & 12.05 & 3.00 & 3.30 & 132.73 & 1.02 & 0,69 \\
\hline UE-236/33 & Borde & 5.45 & 5.39 & 8.85 & 32.21 & 3.93 & 3.97 & 4.94 & 11.85 & 17.43 & - & 5.94 & 8.30 & 0.73 & 1,4 \\
\hline UE-298/143 & Borde & 42.83 & 6.75 & - & 13.52 & 5.88 & 5.14 & - & 11.87 & 6.01 & - & 7.97 & 42.74 & 0.12 & 0,59 \\
\hline UE-335/11 borde & Borde & 19.63 & 8.91 & 14.31 & 11.05 & 6.49 & 15.45 & - & 8.91 & 7.11 & - & 8.11 & 6.33 & 0.79 & 0,8 \\
\hline UE-335/11 aceite & Borde & 8.88 & 0.41 & 0.19 & 0.24 & 3.74 & 78.83 & 5.95 & 0.69 & 0.53 & 0.31 & 0.18 & 1.51 & 8.88 & 6,39 \\
\hline aceite oliva virgen & - & 8.93 & 0.51 & 0.18 & 0.24 & 3.56 & 79.14 & 6.03 & 0.73 & 0.48 & 0.03 & 0.14 & 1.07 & 8.86 & 25,4 \\
\hline
\end{tabular}

Fig. 9: Selección de muestras de Alcalá del Río. Composición de AGs (\%) del aceite extraído en los fragmentos cerámicos correspondientes a los fondos y algunos bordes (\% calculado en relación al área total ocupada por los AGs), así como del hidrocarburo Escualeno (\% calculado en relación al área total de picos del cromatograma).

mortero para facilitar la extracción de las grasas, que se encuentran incrustadas en los poros de la cerámica. Una vez machacada, se pesan $0,25 \mathrm{~g}$ de la muestra y se introduce en un matraz aforado de $100 \mathrm{ml}$. Posteriormente, para convertir los mono-, di- y triglicéridos en ésteres de alquilo, se añaden $40 \mathrm{ml}$ de solución metanólica de metóxido de sodio $0,2 \mathrm{~N}$ y la reacción se realiza a $60^{\circ} \mathrm{C}$ durante 30 minutos, utilizando como refrigerantes unas varillas de 1,20 m de longitud, acopladas al matraz, que actuarán como condensador.

A continuación se retira el equipo de la fuente de calor y se espera hasta que se enfríe. Tras este paso, se añaden $5 \mathrm{ml}$ de ácido sulfúrico en solución metalónica $1 \mathrm{~N}$, se coloca el refrigerante y se vuelve a llevar a ebullición durante 5 minutos. Transcurrido este tiempo, se enfría el matraz de manera brusca bajo el grifo. Con este paso se consigue convertir todos los ácidos grasos libres a ésteres de alquilo. Se quita el refrigerante y se añade agua saturada con $\mathrm{NaCl}$, con objeto de eliminar las impurezas disueltas en los metiles ésteres, como los jabones, hasta que el nivel alcance el cuello del matraz y se agita.

Por último, se añade $2 \mathrm{ml}$ de hexano, se agita vigorosamente y se deja reposar hasta que las dos fases se separen completamente. Con ayuda de una pipeta pasteur se retira la fase orgánica (fase superior) y se traspasa a un matraz cónico esmerilado (este paso se realiza por triplicado). Así se consigue extraer los ésteres de alquilo formados (carácter hidrofóbico) del medio acuoso. Para terminar, se concentra el hexano calentado sobre una placa calefactora. La muestra queda así preparada para su posterior análisis cromatográfico.

\section{CROMATOGRAFÍA DE GAS (GC) Y ESPECTOMETRÍA DE MASA (MS)}

Para la separación e identificación de los AGs se utilizó un equipo de cromatografía de gases HP 5890 serie II con una columna capilar SP2380 de 60m*0'25mm*0,2 $\mu \mathrm{m}$ (Hewlett Packard, Avondale, PA, USA), donde las condiciones cromatográficas seguidas fueron: se utilizó hidrógeno como gas portador; la temperatura inicial del horno fue de $172{ }^{\circ} \mathrm{C}$ y se aplicó un gradiente de temperatura de 172 a $200{ }^{\circ} \mathrm{C}$ a $1,5^{\circ} \mathrm{C} / \mathrm{min}$. La inyección se realizó en modo splitless, siendo la temperatura del inyector de $225^{\circ} \mathrm{C}$ y la del detector de $250^{\circ} \mathrm{C}$. Los AGs fueron identificados por comparación con los tiempos de retención de los patrones correspondientes.

\section{RESULTADOS}

Como se ha indicado en la fig. 6, los tipos de AGs que predominan en los aceites y, por tanto, los que se han estudiado en este trabajo son: ácido palmítico (C16:0), ácido palmitoleico (C16:1), ácido margárico (C17:0), ácido margaroleico (C17:1), ácido esteárico (C18:0), ácido oleico (C18:1), ácido linoleico (C18:2), ácido linolénico (C18:3), ácido araquídico (C20:0), ácido gadoleico (C20:1) y ácido behénico (C22:0). El hecho de mencionar expresamente a lo largo de este trabajo al aceite de oliva "virgen" es debido a que de todos los tipos de aceites de oliva que distinguimos en nuestros días, éste es el que más probablemente se puede relacionar con el que existiera en el período estudiado (ss. VI-II a.C.), ya que es el único que no es sometido a tratamiento químico alguno en su proceso de extracción a partir de la aceituna. 
Francisco José García Fernández, Eduardo Ferrer Albelda, Paloma Álvarez Mateos, María Montaña Durán Barrantes

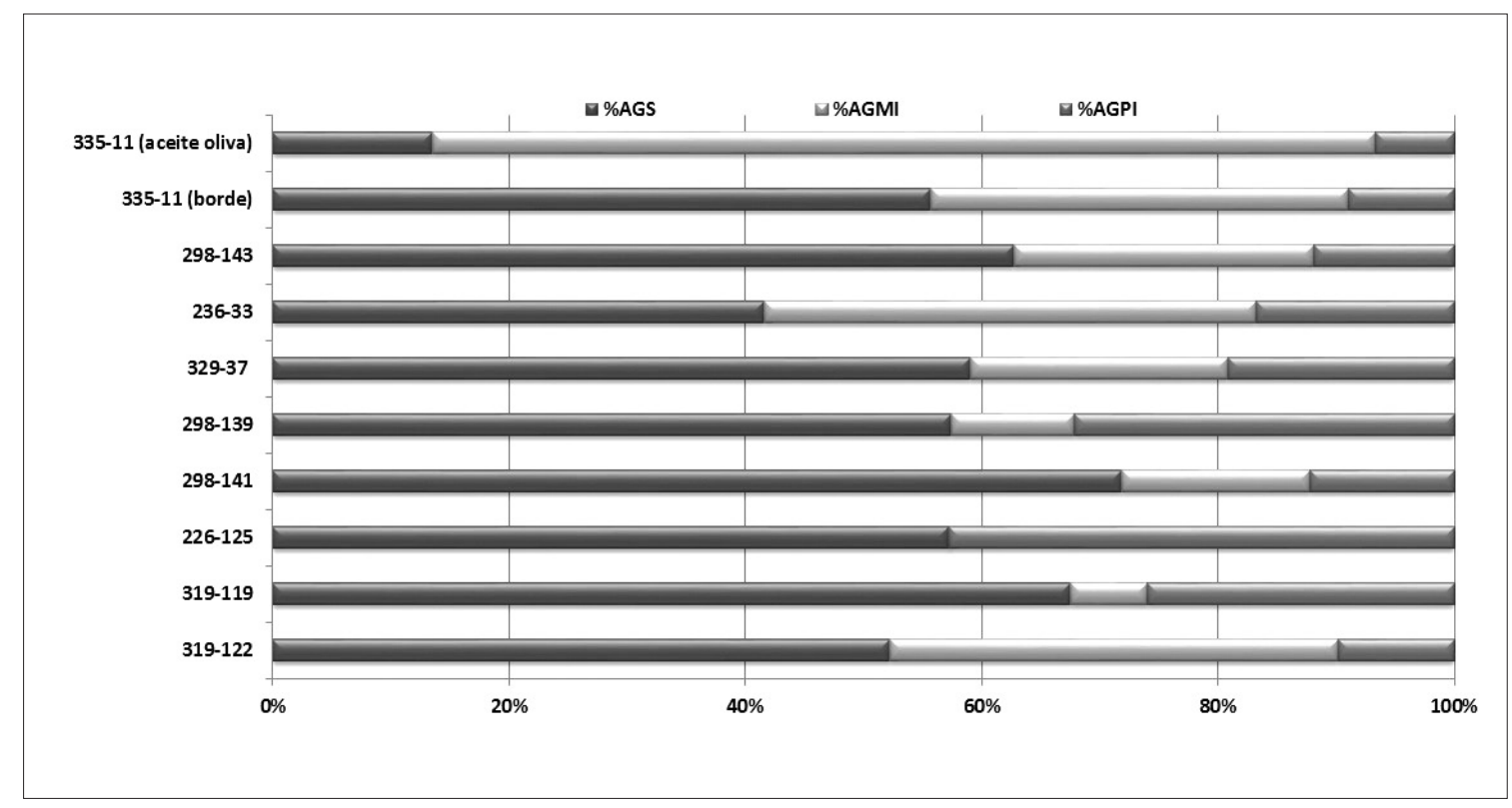

Fig. 10: Selección de muestras de Alcalá del Río. Porcentajes de AGs saturados, monoinsaturados y polinsaturados.

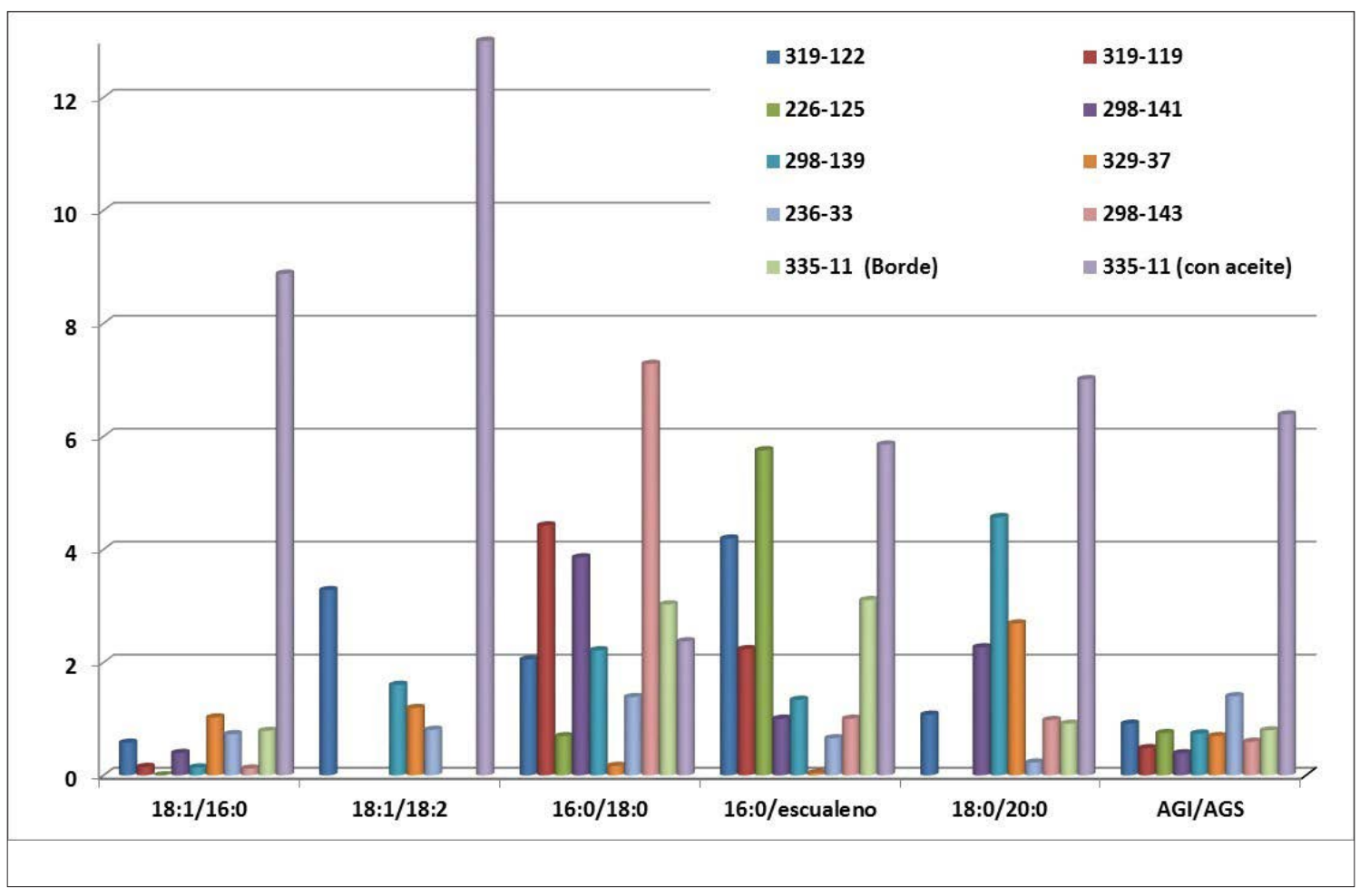

Fig. 11: Selección de muestras de Alcalá del Río. Ratios entre los principales AGs saturados e insaturados, así como de AG insaturados totales frente a AG saturados totales, y del ácido palmítico en relación al escualeno, para cada una de las muestras analizadas. 
Fig. 12: Muestras de Alcalá del Río. Composición de AGs (\%) del aceite extraído en los fragmentos cerámicos correspondientes al resto de los bordes y al fondo UE-326/33.

\begin{tabular}{|l|c|c|c|c|c|c|c|}
\hline MUESTRAS & C14:0 & C16:0 & C18:0 & C18:1 & C18:2 & C16:0/C18:1 & AGI/AGS \\
\hline UE-317/124 & - & 96.67 & 3.33 & - & - & - & - \\
\hline UE-335/9 & 23.86 & 60.24 & 11.97 & 4.11 & - & 0.07 & 0.04 \\
\hline UE-334/16 & - & 84.03 & 15.97 & - & - & - & - \\
\hline UE-326/33 & 7.15 & 58.77 & 9.52 & 24.56 & - & 0.42 & 0.33 \\
\hline UE-303/53 & 4.41 & 81.29 & 9.36 & 4.46 & 0.48 & 0.05 & 0.05 \\
\hline UE-293/31 & 15.82 & 64.79 & 11.13 & 8.26 & - & 0.13 & 0.09 \\
\hline UE-293/32 & 7.53 & 61.89 & 11.0 & 19.58 & - & 0.32 & 0.24 \\
\hline UE-293/33 & - & 53.38 & - & 46.62 & - & 0.87 & 0.87 \\
\hline UE-219/32 & - & 60.48 & - & 39.52 & - & 0.65 & 0.65 \\
\hline UE-329/36 & - & 48.12 & - & 51.88 & - & 1.08 & 1.08 \\
\hline UE-226/118 & - & 23.68 & - & 76.32 & - & 3.22 & 3.22 \\
\hline UE-226/123 & - & 90.12 & 6.03 & 3.85 & - & 0.04 & 0.04 \\
\hline UE-226/124 & - & 94.21 & 2.79 & 3.00 & - & 0.03 & 0.03 \\
\hline UE-226/126 & - & 92.60 & 4.19 & 3.21 & - & 0.03 & 0.03 \\
\hline UE-226/128 & - & 26.11 & - & 73.89 & - & 2.83 & 2.83 \\
\hline UE-298/138 & 12.30 & 71.99 & 9.93 & 5.78 & - & 0.08 & 0.06 \\
\hline
\end{tabular}

El uso de las técnicas análisis por cromatografía de gases y espectrometría de masa permite caracterizar los distintos tipos de AGs y otros polímeros de importancia en la composición de los aceites de uso alimentario (oliva, girasol, pescado, grasa animal, etc.), pudiéndose relacionar la proporción de cada uno de ellos respecto del total de moléculas que aparezcan en la muestra en cada cromatograma. Esto equivaldría a la "huella digital" de cada aceite, con las posibles alteraciones que se puedan dar en la misma por accidentes o condiciones ambientales. Se pueden determinar moléculas de AGs de distinta naturaleza: lineales, polimerizadas y ácidos dicarboxíli$\cos$, producto de la ruptura a partir de un doble enlace. Estos últimos provienen de la degradación oxidativa de los ácidos insaturados (Frankel 2005). Su presencia responde a procesos oxidativos muy rápidos debidos a altas temperaturas, no siendo el caso de los recipientes anfóricos, que no se usaban para calentar, por lo que no se los ha buscado en los cromatogramas analizados.

Los resultados obtenidos en el estudio analítico practicado a la selección de 9 muestras procedentes de Alcalá del Río se detallan en la fig. 9.

Los AGs insaturados son mucho más sensibles a la degradación que los saturados, pero no es extraño que se puedan encontrar embebidos en la matriz arcillosa de las ánforas. De hecho, en la fig. 9 puede observarse su presencia (C18:2 y C18:3) en casi todas las muestras. Como podemos comprobar, hay abundancia relativa de los picos C16:0, C18:0, C18:1, C18:3 y C22:0, así como pequeñas cantidades de otros AGs lineales. Es más, todas las muestras analizadas, menos UE-236/33, UE-329/37 y UE-226/125, contienen más del 20\% de C16:0 respecto del total de AGs, así como cantidades importantes (aproximadamente, entre el 5 y el 15\%) de oleico (C18:1), e incluso el linolénico (C18:3) y behénico (C22:0). Con esto queremos remarcar cómo, a pesar de la degradación de los contenidos orgánicos con el paso del tiempo, el hecho de encontrar aún restos de estos AGs insaturados permiten pensar en que provienen de una concentración significativa en estas ánforas.

En la fig. 10 se exponen los porcentajes de AGs saturados totales (C16:0, C17:0, C18:0, C20:0 y C22:0), AGs monoinsaturados totales (C17:1, C18:1 y $\mathrm{C} 20: 1)$ y AGs polinsaturados totales (C18:2 y C18:3) de las mismas muestras. Hay que destacar la concentración de AGs saturados, según lo que se ha comentado, pero haciendo notar lo significativo que es encontrar en casi todos los casos un valor importante en la contribución de los AGs monoinsaturados, principalmente ácido oleico.

En la fig. 11 (también sobre las muestras alcalareñas) se estudian las relaciones proporcionales entre los ácidos palmítico, esteárico, oleico, linoleico, araquídico y behénico; oleico y palmítico (18:1/16:0), por ser los más abundantes en un aceite de oliva; oleico y linoleico (18:1/18:2), por ser los insaturados con cadena más corta, por lo tanto, con mayor estabilidad entre los AGs insaturados; palmítico y esteárico (16:0/18:0), por la misma razón anterior, pero entre los AGs saturados; y palmítico frente a escualeno (16:0/escualeno), por relacionar el ácido con mayor probabilidad de no degradarse 


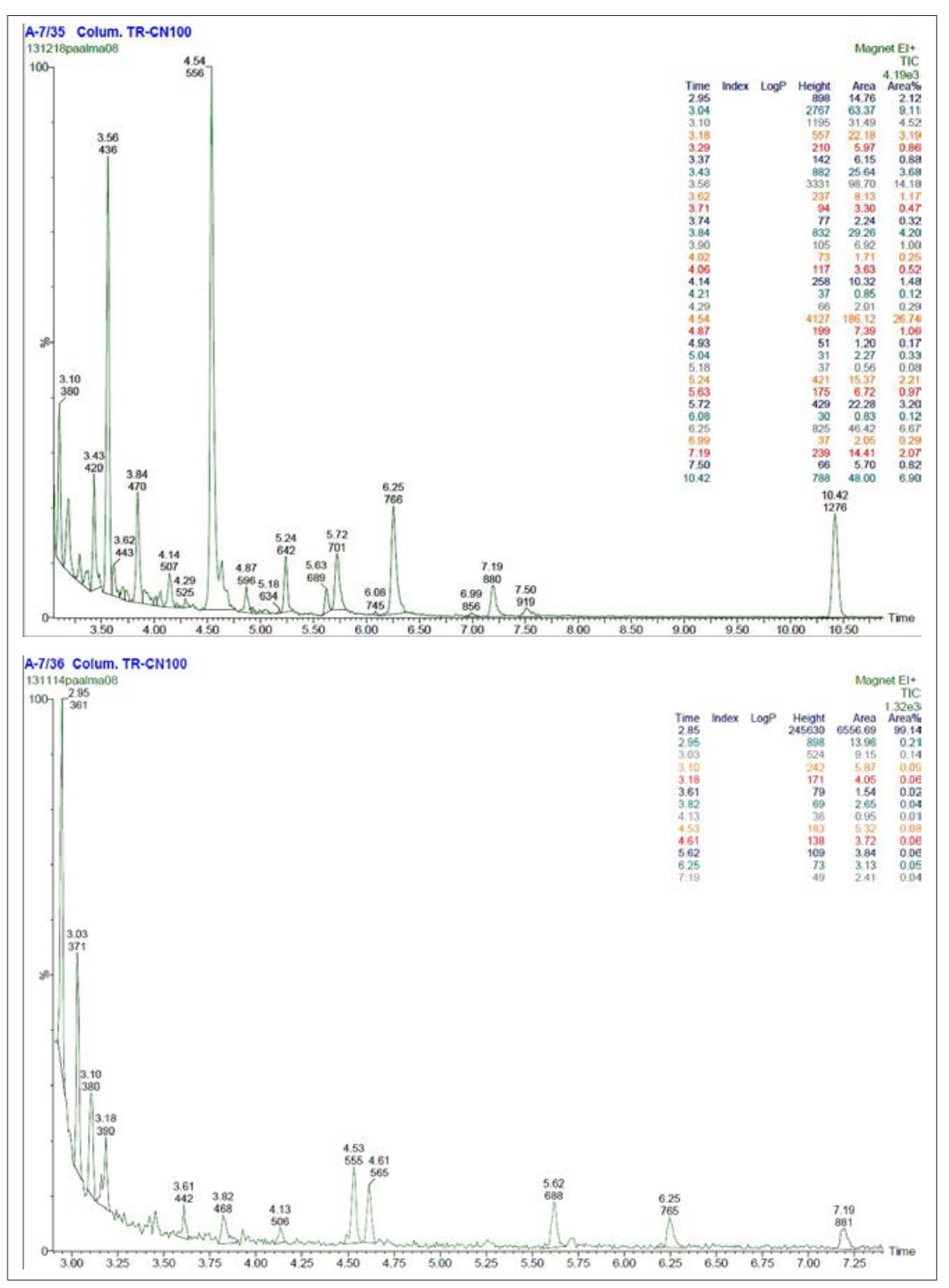

Fig. 13: Muestras de Vico. Cromatogramas correspondientes a las muestras VI-85/A-7/35 (arriba) y VI-85/A-7/36 (abajo).

frente al hidrocarburo más típico en el aceite de oliva. El ácido oleico, al tener un doble enlace o insaturación y mayor número de átomos de carbono, es más inestable que el palmítico, por lo que la relación oleico/palmítico es menor prácticamente en todas las muestras (de 8.8 en el aceite de oliva pasa a $0.4-0.8$ ). En base a esta inestabilidad molecular, debida a las insaturaciones presentes en las moléculas, se ha calculado la relación entre los AGs saturados predominantes en el aceite de oliva (C16:0/C18:0) y se ha advertido que casi todas las muestras están en el mismo orden de magnitud respecto a la relación con este último. En todo caso, resulta evidente que la relación entre AGI/AGS disminuye en todas las muestras en favor del contenido en AGS, lo que se responde, como se ha indicado, a la paulatina degradación de las moléculas más insaturadas por hidrólisis, polimerizaciones, oxidaciones, etc.

Por último, en lo que se refiere a la relación oleico/ linoleico, y con base en la justificación del grado de insaturación molecular, la desviación de los valores de las 
Fig. 14: Muestras de Vico. Composición de AGs (\%) del aceite extraído en los fragmentos cerámicos muestreados. Comparación con los porcentajes de AGs obtenidos en distintos tipos de leche.

\begin{tabular}{|l|c|c|c|c|c|c|}
\hline \multicolumn{1}{|c|}{ MUESTRA } & $\%$ C14:0 & $\%$ C16:0 & $\%$ C16:1 & $\%$ C18:0 & $\%$ C18:1 & $\%$ C18:2 \\
\hline VI-85/A-9/24 & 12,1 & 38,9 & - & 27,3 & 10 & 11,7 \\
\hline VI-85/A-7/35 & 11,3 & 71,7 & 2,8 & - & 8,6 & 5,5 \\
\hline VI-85/A-7/36 & 19,6 & 39,4 & - & - & 23,2 & 17,8 \\
\hline VI-85/A-16/12 & 8 & 40,3 & - & 23,1 & 22,6 & 6 \\
\hline VI-85/A-19sur/20 & 11,1 & 61,8 & 2,6 & 5,7 & 14 & 4,8 \\
\hline VI-85/A-22/23 & 14,9 & 15,7 & - & 30,6 & 24,6 & 14,2 \\
\hline \%AGs leche oveja & 16,7 & 43,3 & 2,3 & 9,5 & 26 & 2,2 \\
\hline \%AGs leche vaca & 13,1 & 36,5 & 1,3 & 12,9 & 22,5 & 13,7 \\
\hline \%AGs leche cabra & 8,85 & 27,4 & 0,89 & 26,2 & 31,2 & 5,5 \\
\hline
\end{tabular}

muestras respecto a la que tiene aceite de oliva añadido es mucho mayor, a excepción de UE-319/122. Esta presenta una gran similitud con la composición típica de un aceite de oliva sometido a los efectos del paso del tiempo, aunque con un mejor grado de conservación si la comparamos con las demás, ya que, de hecho, es la única que coincide en más ratios de los estudiados, con un orden parecido al de la muestra de referencia (UE-335/11 con aceite).

En síntesis, en la selección de muestras de Alcalá del Río, los datos analíticos que más se ajustan a conjeturar la presencia de aceite de oliva en el contenido de las ánforas son la relación entre los AGs saturados 16:0/18:0 y la relación del palmítico con escualeno, próximos en órdenes de magnitud con las relaciones correspondientes en el de oliva, siendo las muestras UE319/122, UE-298/141 y UE-335/11 las que más se acercan, y UE-329/37 la que más se aleja. No obstante, la aparición en los cromatogramas del ácido graso behénico C22:0 así como de escualeno, son también un claro indicio de presencia de aceite de oliva frente a otros tipos de aceite de origen vegetal o animal.

A continuación (fig. 12) se muestran los resultados obtenidos del análisis cromatográfico realizado al resto de los bordes de ánforas. El perfil cromatográfico fue muy escaso en picos y sin presencia de escualeno, encontrándose el ácido mirístico (C14:0), propio del aceite de pescado, que no se obtuvo en ninguno de los cromatogramas de los fondos, así como relaciones oleico/palmítico y AGI/AGS que indican posible presencia de aceite de oliva en dichos fragmentos (especialmente en las muestras UE-329/36, UE-226/118 y UE-226/128). Esto lleva a plantear la posibilidad de que estos contenidos grasos, por encontrarse en una zona superior-externa del ánfora, fueron más propensos a procesos severos de degradación por contaminación ambiental, contacto con otros alimentos, ataques microbianos y factores externos como son la humedad, la temperatura, etc., o bien responden a los productos utilizados como aislantes en el sistema de cierre del recipiente.

En lo que respecta a las muestras de Vico, realizadas todas sobre fondos de ánforas, los resultados han sido más concretos. Las muestras VI-85/A-9/24, VI-85/A-7/35, VI85/A-7/36, VI-85/A-16/12, VI-85/A-19sur/20 y VI85/A-22/23 presentan el mismo perfil de AGs (figs. 13 y 14) en el que se diferencian claramente los picos característicos al ácido mirístico (C14:0) (min 3,82), palmítico (C16:0) (min 4,52), palmitoleico (C16:1) (min 4,87), esteárico $(\mathrm{C} 17: 0)(\min 5,72)$, oleico $(\mathrm{C} 18: 1)(\min 6,25)$ y linoleico $(\mathrm{C} 18: 2)(\min 7,18)$.

Si los analizamos por separado se pueden observar dos grupos bien diferenciados según su composición en AGs (fig. 14): uno formado por las muestras VI-85/A-7/35 y VI-85/A-19sur/20 y otro por las muestras VI-85/A-9/24, VI-85/A-7/36, VI-85/A-16/12 y VI-85/A-22/23. El primer grupo se caracteriza por una alta cantidad de ácido palmítico, alrededor del $70 \%$, bastante elevada sobre todo si lo comparamos con el ácido esteárico, hecho que suele asociarse a la presencia de grasas animales, probablemente de rumiante, como contenido de estas ánforas (Kedrowski et al. 2009). En el segundo grupo la composición de ácido palmítico está en torno al $40 \%$, lo que asociado a la alta cantidad de ácido mirístico y su relación porcentual con el resto de AGs nos invita a pensar en la posibilidad que las muestras del segundo grupo podrían contener algún tipo de derivado lácteo de leche de oveja, cabra o vaca (Atti et al. 2006; Ubaldo et al. 2008; Weintein et al. 2015). Además, en todas las muestras aparece el compuesto 3,5-bis(1,1dimetiletil)-fenol ( $\min 5,61)$; se trata de un compuesto fenólico que podría haberse formado por algún proceso de calentamiento de un $\mathrm{AG}$ monoinsaturado a $270^{\circ} \mathrm{C}$ durante el procesado del alimento (Evershed et al. 2008). 


\section{DISCUSIÓN Y CONCLUSIONES}

La falta de datos arqueológicos objetivos sobre la economía de las comunidades del Bajo Guadalquivir durante el Hierro II ha ocasionado que los escasos acercamientos al tema se conviertan un ejercicio retórico de trasposición al pasado de la información -ciertamente idealizada- sobre Turdetania transmitida por Estrabón, o en vaguedades e inconcreciones sin registros fidedignos ni porcentuales sobre la importancia de la triada mediterránea y de la ganadería en la economía turdetana. Así, a falta de testimonios literarios coetáneos a los procesos económicos que pretendemos describir, el registro arqueológico se convierte en la única fuente de datos para definir aspectos de la base subsistencial de estas poblaciones que, no lo olvidemos, habitaban ecosistemas diversos aunque definidos por tres ámbitos con sus respectivas especificidades económicas: el marino, el fluvial y el terrestre.

Como decimos, los datos arqueológicos permiten un acercamiento al tema desde diversas perspectivas; por un lado, disponemos de registros cada vez más abundantes sobre asentamientos rurales, tanto en lo que se refiere a su distribución en el territorio (Ferrer et al. 2007) y a la relación entre medio rural y centros urbanos (García Fernández 2005, 2007; Ferrer et al. 2008; Ferrer et al. 2011), como a su estructura arquitectónica (González Rodríguez 1987a y b; Carretero 2007a; Vera 2012: 70-72). Proporcionan, por tanto, aproximaciones a la organización de la producción agropecuaria e, indirectamente, a través de diversos artefactos (molinos barquiformes, instrumental lítico con pátina de siega, etc.), la certidumbre de que la agricultura cerealística fue una de las principales actividades en las áreas de campiña, aspecto que se puede contrastar en la última fase del período analizado con los tipos monetales predominantes en cecas de este entorno geográfico, entre las que destaca Carmo (Chaves 2012: 482-488).

No obstante, estos datos son indirectos o tangenciales y no responden -o lo hacen mínimamente- a las incógnitas planteadas en nuestro Proyecto de Investigación acerca de los tipos de alimentos consumidos y su procedencia, la dieta básica, las formas de preparación y las pautas de servicio y consumo en estas comunidades. Tropezamos con un impedimento más: las posibilidades de futuros análisis de isótopos estables del carbono y del nitrógeno de restos óseos humanos hallados en contextos funerarios son nulas si atendemos a la inexistencia de necrópolis en este entorno geográfico y cronológico. Tenemos que recurrir a datos de tiempos inmediatamente anteriores, como los aportados por la necrópolis de La Angorrilla, en Alcalá del Río (Salazar-García 2014), o posteriores, ya de época romana, para analizar con registros objetivos aspectos de la dieta y las patologías derivadas de la misma (para el caso ibicenco, Márquez-Grant 2010).

Las dos únicas vías de estudio posibles, con las herramientas y documentación arqueológica disponibles en este momento, son los análisis antracológicos realizados sobre contextos idóneos procedentes de excavaciones arqueológicas y los estudios de contenido orgánico de los recipientes cerámicos. Los primeros dependen de que exista documentación originaria del entorno geográfico y cronológico en cuestión, circunstancia que hace que sea una línea de estudio de futuro más que de presente porque, con la excepción de algunas excavaciones arqueológicas de urgencia, en la actualidad no hay proyectos -ni muchas posibilidades de que los haya- que asuman estos objetivos en el marco espacio-temporal propuesto. Queda, por tanto, como la vía más fiable y rentable a efectos de lectura histórica, los análisis de contenidos orgánicos de recipientes cerámicos, especialmente de ánforas. A pesar de ello esta línea de investigación apenas ha sido explorada en el contexto geográfico y cronológico objeto de estudio, con la excepción de los trabajos pioneros de P. Carretero (2007) sobre las ánforas T-8.1.1.2 (tipo Tiñosa), cuyos resultados -como se ha visto- coinciden con las muestras analizadas del mismo tipo de Ilipa. En el ámbito ibérico estos estudios cuentan con una larga tradición y volumen de muestras, extendiéndose a una mayor diversidad de formas y productos (véase Tresserras y Matamala 2004). Sin embargo, son las ánforas del Mediterráneo Central las que han proporcionado las primeras evidencias sobre el envasado de carne, aunque en la mayoría de los casos se trata de huesos de mamíferos hallados dentro de las ánforas y no de análisis de marcadores químicos propiamente dichos (Ramon 1995; Tresserras y Matamala 2004: 284). Estos son los antecedentes sobre los que hemos apoyado nuestra investigación, que tiene como objetivo no solo presentar los resultados de las nuevas analíticas sino también exponer las implicaciones económicas, comerciales y culturales de los mismos, que pasamos a sintetizar seguidamente.

a) La primera conclusión es de orden metodológico, esto es, la selección de las muestras cerámicas para el estudio de contenidos orgánicos se debe hacer -en líneas generales- siguiendo criterios contextuales, eligiendo aquellos fragmentos que previsiblemente hayan sido menos alterados 
por los procesos deposicionales y postdeposicionales, y también con criterios "morfológicos", pues se ha demostrado más eficaz la selección de fondos y de partes inferiores del cuerpo que la de bordes, ya que éstos no estuvieron necesariamente en contacto con los contenidos. Así, de las muestras de Vico, todas hechas sobre fondos, los resultados han sido positivos en un 100\% de los casos. En el caso de Alcalá del Río, de las 25 muestras seleccionadas (bordes y ánforas en una proporción 19:6) solo 9 aportaron datos fiables (proporción bordes y fondos 4:5), pues, como ya se ha apuntado, los bordes, además de estar en menor en contacto con el contenido, se encuentran más expuestos a degradaciones, manipulaciones y contaminaciones.

No obstante, el principal problema de la selección de los fragmentos cerámicos es su identificación con tipos anfóricos concretos, cuya ordenación se suele hacer sobre cuerpos completos o, más normalmente, sobre bordes, como es el caso de las ánforas Pellicer B-C y D (Pellicer 1978), mientras que los fondos pueden ofrecer algunas dudas en determinados tipos. Así, en los casos de Alcalá del Río y Vico, tenemos incertidumbres en la adscripción tipológica de varios fragmentos, aunque por motivos contextuales en algunos casos (solo se registraron bordes de Pellicer B-C en los estratos más antiguos), y de pastas cerámicas en otros (claramente diferenciadas de los envases fabricados en la bahía de Cádiz y en Málaga), se pueden atribuir claramente a las producciones "turdetanas".

b) Un segundo asunto, más teórico, es el de la validez de las ánforas como indicio o evidencia de la economía de una región determinada, tanto de los recursos locales destinados a una circulación más o menos restringida, como de los productos importados. Las ánforas son, ante todo, envases de transporte de alimentos sólidos y líquidos, los más utilizados pero no los únicos, si tenemos en cuenta el uso de otros recipientes en materiales perecederos como barriles, capazos y odres. Constituyen, por tanto, una evidencia parcial de la producción agropecuaria (y pesquera) de un área geográfica determinada, que debe ser analizada en relación a otras evidencias (testimonios literarios, numismáticos, arqueológicos, registros paleobiológicos, etc.), cuando existen, pero sin perder la perspectiva de la relatividad -a nivel porcentual- de los datos en el conjunto de la economía.

c) Hecha esta premisa, otro aspecto sobre el que no se ha insistido suficientemente es el del tipo mismo de economía desarrollado por estas comunidades. En el marco cronológico estudiado, entre los ss. V y II a.C., se puede decir que estas sociedades están en transición entre una economía agropecuaria de autosuficiencia, autárquica, con escasa circulación de bienes de consumo, y una economía de base agraria con monocultivos destinados a la comercialización, a la exportación regional o internacional, sobre todo de vino y aceite (y salazones en los ámbitos costeros). Se trata, por tanto, de una región en la que conviven estas dos formas de producción, la de ciudades-estado con una economía agrícola intensiva, destinada a la comercialización y exportación, similar a la de otros estados avanzados del Mediterráneo (Cartago y algunas ciudades etruscas y griegas), y la de estados incipientes y comunidades pre-estatales con una economía extensiva, autosuficiente y de tráficos comerciales de alcance reducido.

Este fenómeno se aprecia singularmente en el porcentaje entre los recipientes de origen exógeno y los de presumible procedencia local (Pellicer B-C y D) en los principales asentamientos de la zona (Ilipa, Caura, ${ }^{*}$ Spal, Cerro Macareno). Esta proporción evoluciona desde la exclusividad de los envases Pellicer B-C en el Bajo Guadalquivir hasta fines del s. V a.C., con un radio de exportación de corto alcance (con la salvedad de algunos ejemplares hallados en la zona del Tajo), al aumento paulatino de las importaciones salazoneras procedentes del litoral gaditano y malagueño (G-11 y G-12 y T-8.2.1.1) y de las ánforas con aceite envasadas en la campiña gaditana (T8.1.1.2), que son mayoritarias en las comunidades ribereñas, como Alcalá del Río. Desde fines del s. V a.C. se puede decir que Gadir se convirtió en el único interlocutor comercial de la región, por donde circularon no solo productos perecederos contenidos en las ánforas sino también vajillas de lujo y semilujo, como la ática y la tipo Kuass respectivamente (Ferrer et al. 2010). Sin embargo, a poca distancia del río Baetis, apenas unos $50 \mathrm{~km}$, en el valle del río Corbones (Vico), la proporción entre importaciones y envases locales es inversa. Esta tendencia tiene una lectura diacrónica, pues si las ánforas Pellicer B-C tuvieron una escasa difusión, las Pellicer D, más tardías, ejemplifican la integración de esta región durante los ss. III-II a.C. en un circuito comercial de mayor alcance que englobaría la costa meridional de Portugal, el Bajo Guadalquivir, la bahía de Cádiz y el N de África, y remiten a contextos políticos distorsionados y dinamizados por las intervenciones directas de Cartago y Roma.

Asimismo, las ánforas, sus morfologías y variedad tipológica, son expresivas de esta transición entre los dos de modos de producción. En las economías en las que una parte de la producción agropecuaria se destinaba 
a la comercialización, habitualmente las ánforas funcionaron como envases "con denominación de origen", es decir, las formas se identificaban con contenidos determinados, como ocurre en algunas producciones, sobre todo de vino, salazones y aceite procedentes de Etruria, Massalia, Campania, del Egeo o del Atlántico. Es el caso de los contenedores de salazón producidos en las comunidades púnicas del "Círculo del Estrecho", básicamente Gadir y Malaca, cuya estandarización es notable y su evolución morfológica sincrónica en todos los territorios. La creación de nuevos tipos (T-8.1.1.2 y T-8.2.1.1) se puede interpretar como la absorción de influencias mediterráneas o, en el caso de las imitaciones grecoitálicas en los talleres de Gadir, como una tendencia mimética destinada a distribuir productos de origen local (vino) aprovechando la fama y buena acogida en los mercados de los vinos de Campania y Magna Grecia.

d) Los envases producidos en el Bajo Guadalquivir, aunque tienen el mismo aire familiar consecuencia de un prototipo común -las ánforas "de saco" fenicias-, sin embargo se caracterizan por una escasa estandarización, es decir, una variabilidad considerable en el tamaño del cuerpo, su perfil y en la morfología de los bordes, sinónimo sin duda de una producción descentralizada en talleres que operan de manera independiente. Las ánforas Pellicer D, no obstante, al final de su secuencia evolutiva sí manifiestan síntomas de estandarización, lo que quizás pueda relacionarse con los fenómenos descritos antes de la integración de estos territorios en una economía de tipo comercial abierta a nuevos mercados y nuevas formas de transporte o estibaje, con la consecuente difusión del tipo. Por este motivo, y por otros que comentaremos seguidamente, dudamos de que las ánforas Pellicer B-C fueran los contenedores exclusivos de un solo producto y sí envases bivalentes y multifuncionales, es decir, que pueden almacenar dos o más tipos de productos, e incluso ser reutilizados, de ahí la importancia de los análisis de contenido.

Como ya ha sido señalado (Bernal 2004: passim), no es infrecuente en la Antigüedad ejemplos de uno y otro comportamiento (ánforas Dr. 28, Keay LIV) y la existencia de otros contenidos alternativos como la carne en salazón (cerdo, ovicápridos, bóvidos, conejo), aceitunas, cerveza, otros productos derivados del vino, etc. (Bernal 2004: 339), de los que hay numerosos ejemplos en todo el Mediterráneo. En el contex to cronológico y geográfico que nos incumbe, los paralelos más significativos quizás sean los de las ánforas púnicas centromediterráneas con contenidos de salazones de carne (Ramon 1995: 264) y los envases de Cancho Roano (Villanueva de la Serena, Badajoz), interpretados como ánforas vinarias y con miel de jara reutilizadas para el almacenamiento de cereales y frutos secos en el primer tercio del s. IV a.C. (Maluquer et al. 1986: 231-232; Guerrero 1991), aunque realmente no se ha demostrado su reutilización y sí que contenían trigo, habas, piñones y almendras (Almagro-Gorbea 1991: 99 y ss).

e) Expuesta esta problemática, es evidente que el estudio de contenidos orgánicos en ánforas y otras cerámicas de almacenamiento es el procedimiento más adecuado para identificar y relacionar formas y productos envasados, aun cuando los resultados no puedan ser interpretados como definitivos hasta que no haya una muestra suficiente para apuntar tendencias generales. Así, en todas las muestras con resultados positivos se han detectado dos tipos de productos, uno de origen vegetal, el aceite de oliva, y otro de origen animal, carne de herbívoro y derivados lácteos (¿queso?). La existencia de aceite envasado corrobora los estudios publicados sobre las ánforas T-8.1.1.2 (Carretero 2007: 66), fabricadas en la campiña gaditana y envasadas con el aceite de los olivos cultivados en los asentamientos rurales tipo "Cerro Naranja" y probablemente en los alrededores de los asentamientos del entorno (Asta, Eboura, Cerro de las Monjas, Cerro de las Vacas, etc.).

Las implicaciones de esta constatación tienen una lectura histórica que presenta algunas certidumbres y muchos interrogantes. Por un lado, la creación del envase T-8.1.1.2, inspirado probablemente en prototipos ibicencos, en una época -s. IV a.C.- en la que la producción de aceite y vino ebusitano está copando los mercados ibéricos, no debió ser casual si tenemos en cuenta que coetáneamente se ha observado la presencia de ejércitos cartagineses en ésta área a fines del s. IV o inicios del III a.C. (Pliego 2003a y b; Ferrer y Pliego 2010a y b; 2013), mientras que la producción a gran escala en la campiña gaditana se generaliza en una fecha algo más tardía (principios del s. III a.C. en Cerro Naranja). Si a esto se añade que el modelo arquitectónico de estos asentamientos rurales también remite a patrones ebusitanos, o centromediterráneos en general (Pardo Barrionuevo 2015), se puede colegir que hubo una importación y adaptación de los modelos de explotación agrícola cartagineses en el entorno inmediato de Gadir, probablemente relacionado con una expansión del territorio de la ciudad hacia la campiña. 
Ahora bien, esta adecuación a una agricultura enfocada al monocultivo con una clara orientación comercial se hizo con capital humano local, como la evidencia arqueológica pone de manifiesto, y no con poblaciones norteafricanas o libiofenicias, como se ha sostenido a veces (López Castro 1992; López Pardo y Suárez 2002; Carretero 2007). El contexto en el que se desarrolla este fenómeno es el de la creciente atención de Cartago hacia el extremo Occidente, desde al menos mediados del s. IV a.C., tendente a estrechar lazos con las comunidades del litoral atlántico y mediterráneo de Iberia e integrarlas en su área de influencia política y en su circuito económico. Los periplos de Hanón e Himilcón son una expresión clara de esta política atlantista de la ciudad norteafricana, y la alusión de Pseudo-Escílax (Per. 1; THA IIB 61a) a emporia cartagineses en la orilla europea del Estrecho, más allá de las Columnas de Heracles, es la confirmación de que, para las fuentes de información griegas de la segunda mitad del s. IV a.C., las tierras oceánicas estaban integradas en su órbita (Ferrer 2008; 2013).

La distribución de las ánforas T-8.1.1.2 (Carretero 2006; 2007a y b) hace de la comercialización del aceite de oliva en este tipo de envase un indicio de cuáles fueron los principales mercados de consumo del aceite gadirita: los antiguos centros fenicios de la costa atlántica de Andalucía y del Algarve, que experimentan un auge demográfico, nuevas fundaciones y un desarrollo económico atribuido a una repoblación fenicia que algunos autores han denominado "gaditanización" (Sousa y Arruda 2010), y las comunidades ribereñas de la ensenada bética, integradas también en este mercado donde el elemento púnico es el predominante (Ferrer et al. 2010).

f) Por su parte, los análisis de contenidos de las ánforas de Vico aportan datos muy interesantes sobre posibles restos orgánicos compatibles con grasas de animales, carne en salazón o macerada en especias y derivados de productos lácteos (queso, requesón), aunque en un contexto económico diferente del anterior, a pesar de su cercanía geográfica. Así, por un lado, parecen confirmar lo ya apuntado supra: que las ánforas "turdetanas" de fabricación local y distribución regional eran contenedores polivalentes que transportaron, al menos, aceite, carne y derivados lácteos; por otra parte, los resultados de Vico registran la costumbre también documentada en ámbitos fenicio-púnicos del Mediterráneo central del transporte en ánforas de carne procesada para su comercialización o distribución regional, y remite a una economía agropecuaria de antigua implantación en la zona. Los estudios sobre el paisaje predominante en el valle del Corbones durante el I ${ }^{\mathrm{er}}$ milenio a.C. son ilustrativos de cómo hubo una coexistencia entre cultivos de secano, sobre todo cereales, olivares y dehesas, que en los ss. VII y VI a.C. mantuvieron a una cabaña bovina, caprina, ovina y porcina (Ferrer et al. 2011). De hecho, en la última fase del Hierro I de Montemolín los edificios C y D estaban dedicados al sacrificio ritual de reses (Bandera et al. 1995, 2000; Bandera et al. 1999; Bandera y Ferrer Albelda 1998), y es plausible que, desaparecido este centro ceremonial en la primera mitad del s. VI a.C., la población del asentamiento de Vico mantuviera una ocupación económica de estructura similar.

\section{NOTA}

1. Este trabajo se ha realizado en el marco del Grupo de Investigación PAI HUM-152 y ha sido financiado por los proyectos "Sociedad y Paisaje. Alimentación e identidades culturales en Turdetania-Bética (Siglos VIII a.C.-II d.C.)" (HAR2011-25708/Hist) e "Identidades étnicas e identidades cívico-políticas en la Hispania romana: el caso de la Turdetania-Bética" (HAR2012-32588).

\section{BIBLIOGRAFÍA}

ALMAGRO-GORBEA, M. (1991): La alimentación en el palacio orientalizante de Cancho Roano, Gerión. Homenaje al Dr. Michel Ponsich, Madrid, 95-113.

ARRUDA, A. M. (2001): Importações púnicas no Algarve: cronología e significado, Os punicos no Extremo Occidente. Actas do Coloquio Internacional (A.A. Tavares ed.), Lisboa, 77-78.

ATTI N.; ROUISSI, H.; OTHMANE M.H. (2006): Milk production, milk fatty acid composition and conjugated linoleic acid (CLA) content in dairy ewes raised on feedlot or grazing pasture, Livestock Science 104, 121-127. DOI: https://doi.org/10.1016/j.livsci.2006.03.014

BANDERA, M. L. de la; FERRER, E. (1998): Indicios de carácter económico y ritual de tradición próximo oriental en el sur de Iberia, Actas del Congreso: El Mediterráneo en la Antigüedad: Oriente y Occidente (J. Cunchillos et al. 1998 eds.), Sapanu. Publicaciones en Internet II.

BANDERA, M. L. de la; FERRER, E. (2002): Secuencia estratigráfica tartesia y turdetana de Vico (Marchena, Sevilla), Spal 11, 121-149. DOI: https://doi.org/10.12795/spal.2002.111.06

BANDERA, M. L. de la; CHAVES, F.; FERRER, E. (1999): Ganado, sacrificio y manipulación de carnes. Una propuesta aplicada al período orientalizante, II Congreso de Arqueología Peninsular, vol. 3, Alcalá de Henares, 213-219. 
BANDERA, M.L. de la; CHAVES, F.; FERRER, E.; BERNÁLDEZ, E (1995): El yacimiento tartésico de Montemolín, Tartessos. 25 años después 1968-1993, Jerez de la Frontera (Cádiz), 315-332.

BANDERA, M. L. de la; CHAVES, F.; ORIA, M.; FERRER, E.; GARCÍA, E.; MANCEBO, J. (1993): Montemolín. Evolución del asentamiento durante el Bronce Final y el período orientalizante (campañas de 1980 y 1981), AAC 4, 15-48.

BELÉN, M. (2006): Ánforas de los siglos VI-IV a. C. en Turdetania, Spal 15, 217-246.

DOI: https://doi.org/10.12795/spal.2006.i15.11

BELÉN, M.; ANGLADA, R.; ESCACENA, J.L.; JIMÉNEZ, A.; LINEROS, R.; RODRÍGUEZ, I. (1997): Arqueología en Carmona (Sevilla). Excavaciones en la Casa-Palacio del Marqués de Saltillo, Sevilla.

BERNAL, D. (2004): Ánforas de transporte y contenidos. A propósito de la problemática de algunos envases de los ss. II y I a.C., Actas de los XVI Encuentros de Historia y Arqueología. Las industrias alfareras y conserveras fenicio-púnicas de la bahía de Cádiz (D. Bernal Casasola ed.), Córdoba, 321-378.

BOSKOU, D. (1996): Olive oil, chemistry and technology, Champaign.

CAÑABATE, M.L.; SÁNCHEZ VIZCAÍNO, A. (1995): Análisis de indicadores bioquímicos del contenido de recipientes arqueológicos, Complutum 6, 281-291.

CARRETERO, P. A. (2004): Las producciones cerámicas de ánforas tipo 'Campamentos Numantinos' y su origen en San Fernando (Cádiz): los hornos de Pery Junquera, Actas del Congreso Internacional FIGLINAE BAETICAE. Talleres alfareros y producciones cerámicas en la Bética romana (ss. II a.C. - VII d.C.) (L. Lagóstena y D. Bernal eds.), BAR International Series 1266, Oxford, 427-440.

CARRETERO, P. A (2006): Difusión de ánforas tipo "Tiñosa" en Algarve (Portugal) y la comercialización de productos agrícolas púnico-turdetanos entre los siglos V y III a.C., Actas do $2^{\circ}$ Encontro de Arqueologia do Algarve. Xelb 5, 305-316.

CARRETERO, P. A (2007a): Agricultura y Comercio Púnico-Turdetano en el Bajo Guadalquivir. El inicio de las explotaciones oleícolas peninsulares (siglos IV-II a.C.), BAR Internacional Series 1703, Oxford.

CARRETERO, P. A (2007b): Las villas agrícolas púnico-turdetanas de la campiña gaditana (Cádiz-España), Las ciudades fenicio-púnicas en el Mediterráneo occidental (J.L. López Castro ed.), Almería, 187-208.

CARRETERO, P. A.; GARCÍA, R.; FELIÚ, M.J. (2004): Ánforas tipo Tiñosa: Análisis de la caracterización químicomineralógica y su perspectiva histórica, Avances en Arqueometría 2003 (M. José Feliú et al. eds.), Cádiz, 183-198.

CARRETERO, P. A.; ARRUDA, A. M.; CARRETERO, M. T.; PETIT, M. D.; GARCÍA, R.; RUCANDIO, M. I. (2006): Archaeometry of a New Punico-Turdetano Amphora Type: The Oil Amphorae from the Campiña Gaditana (Cádiz, Spain), 36th International Symposium on Archaeometry (ISA 2006), Quebec City (Canadá), <http://eprints.jiia. it:8080/212/> (consulta 30-XII-2013).
CHAVES, F. (2012): La ceca de Carmo, Carmona Romana (A. Caballos ed.), Sevilla, 463-497.

CHAVES, F.; BANDERA, M. L. de la (1987): Excavaciones arqueológicas en el Cortijo de Vico, AAA/1987, vol. III, 372-379.

CHAVES, F.; BANDERA, M. L. de la (1991): Aspectos de la urbanística en Andalucía occidental en los siglos VII-VI a.C. a la luz del yacimiento de Montemolín (Marchena, Sevilla), II Congresso Internazionale di Studi Fenici e Punici, vol. II, Roma, 691-714.

CHAVES, F.; BANDERA, M. L. de la; FERRER, E.; BERNÁLDEZ, E. (2000): El complejo sacrificial de Montemolín, Actas del IV Congreso Internacional de Estudios Fenicios y Púnicos, vol. II, Madrid, 573-581.

CHAVES, F.; KERMORVANT, A.; MARTÍNEZ, J.B.; FERRER, E.; GARCÍA, F. J.; MOURONVAL, M. (e.p.): Informe preliminar de la actividad puntual «Prospecciones Geofísicas y estudios paleoambientales en el Término Municipal de Marchena (Sevilla)», AAA/2007, Sevilla.

CHAVES, F.; GARCÍA, F. J.; GARCÍA, E.; FERRER, E.; BANDERA, M. L.; ORIA, M. (2010): Economía rural y consumo urbano en el sur de la Península Ibérica: el Bajo Guadalquivir (siglos V a.C.-II d.C.), L'Africa Romana XVIII, 1083-1100.

CHIC, G. (2007): Ilipa romana: entre el prestigio y el mercado, I Congreso de Historia de Alcalá del Río: "Ilipa Antiqua. De la Prehistoria a la Época Romana” (E. Ferrer et al. eds.), Sevilla, 149-170.

DE FRUTOS, G.; MUÑOZ, A. (1994): Hornos púnicos de Torre Alta (San Fernando, Cádiz), Arqueología en el entorno del Bajo Guadiana (J. Campos et al. coords.), Huelva, 393-414.

DOMÍNGUEZ, M. C.; CABRERA, P.; FERNÁNDEZ, J. (1988): Cero de la Cabeza (Santiponce, Sevilla), NAH 30, 119-186.

EERKENS, J. W. (2005): GC-MS analysis and fatty acid ratios of archaeological potsherds from the Western Great Basin of North America, Archaeometry 47 (1), 83-102. DOI: https://doi.org/10.1111/j.1475-4754.2005.00189.x

EVERSHED, R. P. (2008a): Organic residue analysis in Archaeology: the archaeological biomarker revolution, Archaeometry 50 (6), 895-924.

DOI: https://doi.org/10.1111/j.1475-4754.2008.00446.x

EVERSHED, R. P. (2008b): Experimental approaches to the interpretation of absorbed organic residues in archaeological ceramics, World Archaeology 40, 26-47. DOI: https://doi.org/10.1080/00438240801889373

EVERSHED, R. P .; HERON, C.; CHARTERS, S.; GOAD, L. J. (1992): The survival of food residues: new methods of analysis, interpretation and application, Proceedins of the British Academy 77, 187-208.

EVERSHED, R. P.; DUDD, S. N.; COPLEY, M. S.; BERSTAN, R.; STOTT, A. W.; MOTTRAM, H.; BUCKLEY, S. A.; CROSSMAN, Z. (2002): Chemistry of archaeological animal fats, Accounts of Chemical Research 35, 660-668. DOI:https://doi.org/10.1021/ar000200f 
EVERSHED, R. P.; COPLEY, M. S.; DICKSON, L.; HANSEL, F. A. (2008): Experimental evidence for the processing of marine animal products and other commodities containing polyunsaturated fatty acids in pottery vessels, Archaeometry 50 (1), 101-113.

DOI: https://doi.org/10.1111/j.1475-4754.2007.00368.x

FENNEMA, O. R. (2000): Química de los alimentos, Zaragoza.

FERNÁNDEZ FLORES, A.; RODRÍGUEZ AZOGUE, A. (2007): Vida y muerte en la Ilipa tartésica, I Congreso de Historia de Alcalá del Río: "Ilipa Antiqua. De la Prehistoria a la Época Romana" (E. Ferrer et al. eds.), Sevilla, 69-92.

FERNÁNDEZ FLORES, A.; RODRÍGUEZ, A.; CASADO, M.; PRADOS, E. (coords.) (2014): La necrópolis de época tartésica de La Angorrilla. Alcalá del Río, Sevilla, Sevilla.

FERNÁNDEZ GÓMEZ, F.; CHASCO, R.; OLIVA, D. (1979): Excavaciones en El Cerro Macareno. La Rinconada. Sevilla (Cortes E-F-G. Campaña 1974), NAH 7, 7-93.

FERRER, E. (1995): Los púnicos en Iberia: Análisis historiográfico y arqueológico de la presencia púnica en el sur de la Península Ibérica, Tesis Doctoral inédita, Universidad de Sevilla.

FERRER, E. (2008): Cartago y la transmisión de los conocimientos geográficos sobre el Extremo Occidente, Libyae lustrare extrema, Realidad y literatura en la visión grecorromana de África. Estudios en honor del Profesor Jehan Desanges (J.M. Candau, F.J. González Ponce y A.L. Chávez coords.), Sevilla, 53-65.

FERRER, E. (2013): La piratería en los tratados entre Cartago y Roma, Piratería y seguridad marítima en el Mediterráneo Antiguo (A. Álvarez-Ossorio, E. Ferrer y E. García Vargas coords.), Sevilla, 95-125.

FERRER, E.; BANDERA, M. L. de la (2005): El orto de Tartessos: La colonización agraria durante el período orientalizante, El período orientalizante. Actas del III Simposio Internacional de Arqueología de Mérida. Protohistoria del Mediterráneo Occidental (S. Celestino y J. Jiménez Ávila eds.), Anejos de AEspA XXXIII, vol. I, Mérida, 565-574.

FERRER, E.; BANDERA, M. L. de la (2007): Santuarios, aldeas y granjas: El poblamiento durante el Bronce Final y el Período Orientalizante, Arqueología en Marchena. El poblamiento antiguo y medieval en el valle medio del río Corbones (E. Ferrer coord.), Sevilla, 45-87.

FERRER, E.; GARCÍA FERNÁNDEZ, F. J. (2007): Primeros datos sobre la Ilipa turdetana, I Congreso de Historia de Alcalá del Río: "Ilipa Antiqua. De la Prehistoria a la Época Romana" (E. Ferrer Albelda et al. eds.), Sevilla, 103-130.

FERRER, E.; GARCÍA FERNÁNDEZ, F. J. (2008): La cerámica turdetana, Cerámicas hispanorromanas. Un estado de la cuestión (D. Bernal y A. Ribera eds.), Cádiz, 202-219.

FERRER, E.; BANDERA, M. L. de la; GARCÍA, F. J. (2007): El poblamiento rural protohistórico en el Bajo Guadalquivir, Arqueología de la tierra. Paisajes rurales de la protohistoria peninsular (A. Rodríguez e I. Pavón eds.), Cáceres, 195-224.
FERRER, E.; GARCÍA, F. J.; ESCACENA, J. L. (2010): El tráfico de productos púnicos en el antiguo estuario del Guadalquivir, Mainake XXXII (1), 61-89.

FERRER, E.; GARCÍA, F.J.; SÁNCHEZ, F. (2011): De la aldea al oppidum. El paisaje rural en el valle del Corbones durante el Ier milenio a.C., Carmona. 7000 años de historia rural. Actas del VII Congreso de Historia de Carmona (M. A. Piñero coord.), Carmona (Sevilla), 75-109.

FERRER, E.; GARCÍA, E.; GARCÍA, F.J. (2008): Inter aestuaria Baetis. Espacios naturales y territorios ciudadanos prerromanos en el Bajo Guadalquivir, Mainake XXX, 217-246.

FERRER, E.; PLIEGO, R. (2010a): ... Auxilium consanguineis karthaginiensis misere: un nuevo marco interpretativo de las relaciones entre Cartago y las comunidades púnicas de Iberia, Mainake XXXII (1), 525-557.

FERRER, E.; PLIEGO, R. (2010b): Carthaginian garrisons in Turdetania: the monetary evidence, Trade and trade route in Pre-islamic North Africa, London, 33-41.

FERRER, E.; PLIEGO, R. (2013): Cartago e Iberia antes de los Barca, Fragor Hannibalis. Aníbal en Hispania (M. Bendala Galán edit. cient.), Alcalá de Henares, 108-133.

FRANKEL, E. N. (2005): Lipid Oxidation ( $2^{\circ}$ ed.), Londres.

GARCÍA FERNÁNDEZ, F. J. (2005): El poblamiento postorientalizante en el Bajo Guadalquivir, El período orientalizante. Actas del III Simposio Internacional de Arqueología de Mérida. Protohistoria del Mediterráneo Occidental (S. Celestino y J. Jiménez eds.), Anejos de AEspA XXXIII, vol. II, Madrid, 891-900.

GARCÍA FERNÁNDEZ, F. J. (2007): El poblamiento turdetano en la comarca de Marchena, Arqueología en Marchena. El poblamiento antiguo y medieval en el valle medio del río Corbones (E. Ferrer coord.), Sevilla, 89-142.

GARCÍA FERNÁNDEZ, F. J. (2012): Tartesios, túrdulos, turdetanos. Realidad y ficción de la homogeneidad étnica de la Bética romana, Romanización, fronteras y etnias en la Roma antigua: el caso hispano (J. Santos et al. coords.), Revisiones de Historia Antigua VII, Vitoria, 691-734.

GARCÍA FERNÁNDEZ, F.J.; FERRER, E. (2011): Das turdetanische Emporion Spal. Der punische Handelsverkehr im vorrömischen Sevilla (5. - 2. Jh. V. Chr.), Madrider Mitteilungen 52, 335-374.

GARCÍA FERNÁNDEZ, F.J.; GARCÍA VARGAS, E. (2010): Entre gaditanización y romanización: repertorios cerámicos, alimentación e integración cultural en Turdetania (siglos III-I a.C.), De la cuina a la taula. IV Reunió d'Economia en el Primer Mil.lenni a.C. (C. Mata Parreño et al. eds.), Sagvntvm-PLAV Extra-9, Valencia, 115-134.

GARCÍA FERNÁNDEZ, F.J.; GARCÍA VARGAS, E. (2012): Los hornos alfareros de tradición fenicia en el valle del Guadalquivir y su perduración en época romana: aspectos tecnológicos y sociales, Spal 21, 9-39. DOI: https://doi.org/10.12795/spal.2012.i21.01 
GARCÍA FERNÁNDEZ, F. J.; GONZÁLEZ ACUÑA, D. (2007): Secuencias estratigráficas y contextos culturales de la Sevilla prerromana, $V$ Congreso de Historia de Carmona. Los orígenes de la ciudad: la Carmona Protohistórica (M. Bendala y M. Belén eds.), Carmona (Sevilla), 525-566.

GARCÍA VARGAS, E. (2009): Las ánforas republicanas de Hispalis (Sevilla) y la "cristalización" del repertorio anfórico provincial, Estudios de Prehistoria y Arqueología en Homenaje a Pilar Acosta Martínez (R. Cruz-Auñón y E. Ferrer coords.), Sevilla, 437-464.

GARCÍA VARGAS, E.; GARCÍA FERNÁNDEZ, F.J. (2009): Romanización y consumo: cambios y continuidades en los contextos cerámicos de Hispalis en épocas turdetana y romano-republicana, Spal 18, 121-155. DOI: https://doi.org/10.12795/spal.2009.i18.08

GARCÍA VARGAS, E.; MORA, M.; FERRER, E. (1989): Estudios sobre cerámicas ibéricas andaluzas: Montemolín (Marchena, Sevilla), Habis 20, 217-243.

GARNIER, N. (2007): Analyse de résidus organiques conservés dans des amphores: un état de la question, $L R C W$ 2. Late Roman Coarse Wares, Cooking Wares and Amphorae in the Mediterranean: Archaeology and Archaeometry, BAR International Series, 1662 (I), Oxford, 39-57.

GARNIER, N.; SILVINO, T.; BERNAL, D. (2011): L'identification du contenu des amphores: huile, conserves de poissons et poissage, SFECAG, Actes du congrès d'Arles, Marsella, 397-416.

GONZÁLEZ RODRÍGUEZ, R. (1987a): Excavaciones de urgencia en el Cerro Naranja (Jerez de la Frontera, Cádiz), AAA/1985, vol. III, Sevilla, 90-96.

GONZÁLEZ RODRÍGUEZ, R. (1987b): El yacimiento prerromano de "Cerro Naranja" (Finca de Los Garciagos, Jerez de la Frontera), Cádiz en su Historia. VI Jornadas de Historia de Cádiz, Cádiz, 27-44.

GUERRERO, V. (1991): El palacio-santuario de Cancho Roano (Badajoz) y la comercialización de ánforas fenicias indígenas, RStudFen XIX (1), 49-82.

HERON, A.; EVERSHED, P.; GOAD, J. (1991): Effects of migration of soil lipids on organic residues associates with buried potsherds, Journal of Archaeological Science 18, 641-659. DOI: https://doi.org/10.1016/0305-4403(91)90027-M

IUPAC (1992a): Preparation of the fatty acid methyl esters 2.301, Standard Methods for the Analysis of Oils, Fats and Derivatives ( $7^{\mathrm{a}}$ ed), Oxford.

IUPAC (1992b): Gas-liquid chromatography of fatty acid methyl esters 2.302, Standard Methods for the Analysis of Oils, Fats and Derivatives ( $\left.7^{\mathrm{a}} \mathrm{ed}\right)$, Oxford.

IZQUIERDO, P.; TORRES, G.; BARBOZA, Y.; MÁRQUEZ, E.; ALLARA, M. (2000): Análisis proximal, perfil de ácidos grasos, aminoácidos esenciales y contenido de minerales en doce especies de pescado de importancia comercial en Venezuela, Archivos Latinoamericanos de Nutrición 50 (2), 187-194
JIMÉNEZ, J.; RONDÓN, D.; MARTÍNEZ, L.; MATAIX, J. (2001): Composición química de los aceites de oliva, Aceite de oliva virgen: nuestro patrimonio alimentario (J. Mataix ed.), Granada, 115-136.

KBIRI ALAOUI, M.; MLILOU, B. (2007): Producción de ánforas y actividad comercial, Kuass (Asilah, Marruecos). Alfarería y economía (ss. V-I a.C.) (M. Kbiri Alaoui), SagvntvmPLAV Extra-7, Valencia, 65-100.

KEDROWSKI, B. L.; CRASS, B.A .; BEHM, J. A.; LUETKE, J. C.; NICHOLS, A. L.; MORECK, A. M.; HOLMES, C. E. (2009): GC/MS analysis of fatty acids from ancient hearth residues at the Swan Point archaeological site, Archaeometry $51(1), 110-122$. DOI: https://doi.org/10.1111/j.1475-4754.2008.00384.x

LÓPEZ CASTRO, J. L. (1992): Los libiofenicios: una colonización agrícola cartaginesa en el sur de la Península Ibérica, RStudFen XX (1), 47-65.

LÓPEZ PARDO, F.; SUÁREZ, J. (2002): Traslados de población entre el Norte de África y la Península Ibérica en los contextos coloniales fenicio y púnico, Gerión 20 (1), 113-152.

LÓPEZ SABATER, M. C.; BOATELLA, J.; DE LA TORRE, M. C. (1985): Evolución de la composición de ácidos grasos a lo largo de la maduración de diferentes variedades de aceitunas, ARXIUS de l'Esc. Sup. d'Agricultura. Barcelona 8, 33-42.

LUZÓN, J. M. (1973): Excavaciones en Itálica: estratigrafía en el Pajar de Artillo, EAE 78, Madrid.

MALUQUER, J.; CELESTINO, S.; GRACIA, F.; MUNILLA, G. (1986): El santuario protohistórico de Zalamea de la Serena (Badajoz), III (1983-1986), Barcelona.

MÁRQUEZ-GRANT, N. (2010): La época púnica desde una perspectiva biológica: aportaciones del estudio de los restos humanos de la isla de Ibiza, Mainake XXXII (1), 159-203.

MILLÁN, J. (1989): Ilipa Magna, Alcalá del Río (Sevilla).

MIRÓ, J. (1983-84): Algunas consideraciones sobre las ánforas ibéricas Mañá B-3, Pyrenae 19-20, 157-189.

MONTEDORO, G.F.; TATICCHI, A.; ESPOSTO, S.; SELVAGGINI, R.; URBANI, S.; SERVILLI, M. (2007): Antioxidants in virgin olive oil, Olea 26, 5-13.

MORA, G. M.; ROMO, A. S. (2006): Intervención arqueológica de urgencia en el Palacio Arzobispal de Sevilla. Sectores de Archivo y Tribunal. Primera fase de los trabajos. Sondeos I-II-IV. Aportaciones a la Sevilla republicana, AAA/2003, vol. III, Sevilla, 179-196.

NEWMARK, H. L. (1999): Squalene, olive oil, and cancer risk. Review and hypothesis, Annals of the New York Academy of Sciences 889, 193-203. DOI: https://doi.org/10.1111/j.1749-6632.1999.tb08735.x

NIVEAU DE VILLEDARY, A. M. (2002): Las ánforas turdetanas del tipo Pellicer-D. Ensayo de clasificación, Spal 11, 233-252. DOI: https://doi.org/10.12795/spal.2002.i11.12

ORTIZ, A.; CONLIN HAYES, E. (e.p.): Actividad arqueológica preventiva en c/ Doctor Fleming 13-15 de Carmona (Sevilla), AAA/2007, Sevilla. 
PARDO, C. A. (2015): Economía y sociedad rural fenicia en el Mediterráneo occidental, Sevilla.

PELLICER, M. (1978): Tipología de las ánforas prerromanas del Guadalquivir, según el Cerro Macareno (Sevilla), Habis 9 , 365-400.

PELLICER, M. (1982): Las cerámicas del mundo fenicio en el Bajo Guadalquivir: evolución y cronología según el Cerro Macareno (Sevilla), Phöinizier im Westen, Madrider Beiträge 8, Mainz am Rhein, 371-404

PELLICER, M.; BENDALA, M.; ESCACENA, J.L. (1983): El Cerro Macareno, EAE 124, Madrid.

PLIEGO, R. (2003a): Sobre el reclutamiento de mercenarios turdetanos. El campamento cartaginés de El Gandul (Alcalá de Guadaíra, Sevilla), Habis 34, 39-56.

PLIEGO, R (2003b): Un campamento cartaginés del siglo IV a.C. en El Gandul (Alcalá de Guadaíra, Sevilla), RStudFen XXXI (1), 31-67.

RAMON, J. (1995): Las ánforas fenicio-púnicas del Mediterráneo Central y Occidental, Barcelona.

REGERT, M.; BLAND, H. A.; DUDD, S. N.; VAN BERGEN, P. F.; EVERSHED, R. P. (1998): Free and bound fatty acid oxidation products in archaeological ceramic vessels, Proccedings of the Royal Society of London, series B 265, 2027-2032. DOI: https://doi.org/10.1098/rspb.1998.0536

REGERT, M.; GARNIER, N.; DECAVALLAS, O.; CREN-OLIVÉ, C.; ROLANDO, C. (2003): Structural characterization of lipid constituents from natural substances preserved in archaeological environments, Measurement Science and Technology 14: 1620-1630. DOI: https://doi.org/10.1088/0957-0233/14/9/313

RODERO, A. (1991): Las ánforas del Mediterráneo Occidental en Andalucía, TP 48, 275-298.

RODRÍGUEZ RODRÍGUEZ, I. (2001): Las áreas artesanales: los alfares, Carmona Romana. II Congreso de Historia de Carmona (A. Caballos ed.), Carmona (Sevilla), 311-320.

RUIZ CABRERO, L.A.; MEDEROS, A. (2002): Comercio de ánforas, escritura y presencia fenicias en la Península Ibérica, SEL 19, 89-120

RUIZ MATA, D. (1995): El vino en la época prerromana en Andalucía Occidental, Arqueología del vino. Los orígenes del vino en Occidente (S. Celestino ed.), Jerez de la Frontera (Cádiz), 157-212.

RUIZ MATA, D.; CORDOBA, I. (1999): Los hornos turdetanos del Cerro Macareno. Cortes H.I y H.II, Actas del XXIV Congreso Nacional de Arqueología, vol. 3, Cartagena, 95-105.
SÁEZ ROMERO, A. M. (2005): Aproximación a la tipología de la cerámica común púnico-gaditana de los ss. II-II, Spal 14, 145-177. DOI: https://doi.org/10.12795/spal.2005.i14.06

SÁEZ ROMERO, A. M. (2008): La producción cerámica en Gadir en época tardopúnica (siglos -III/-I), BAR International Series, 1812 (2 vols.), Oxford.

SÁEZ, A.; DÍAZ, J. J.; MONTERO, R. (2004): Acerca de un tipo de ánfora salazonera púnico-gadirita, Habis 35, 109-133.

SALAZAR-GARCÍA, D. C. (2014): Aproximación a la dieta de la población de la Angorrilla. Resultados preliminares de los análisis de isótopos estables del carbono y del nitrógeno en restos humanos, La necrópolis de época tartésica de $L a$ Angorrilla. Alcalá del Río, Sevilla (Á. Fernández Flores et al. coords.), Sevilla, 605-615.

SMITH, T. J.; YANG, G. Y.; SERIL, D. N.; LIAO, J.; KIM, S. (1998): Inhibition of 4-(methylnitrosamino)-1-(3-pyridil)1-butanone-induced lung tumorigenesis by dietary olive oil and squelene, Carcinogenesis 19, 703-706. DOI: https://doi.org/10.1093/carcin/19.4.703

SOUSA, E.; ARRUDA, A. M. (2010): A gaditanizaçao do Algarve, Mainake XXXII (2), 951-974.

SURRA, J. C.; ARNAL, C.; MARTÍNEZ, M. V.; OSADA, J. (2005): Efecto de la composición de la grasa de la dieta en la aterogénesis, Revista Española de Obesidad 3, 328-339.

TRESSERRAS, J J.; MATAMALA, J. C. (2004): Los contenidos de las ánforas en el Mediterráneo Occidental. Primeros resultados, La circulació d'ámfores al Mediterrani occidental durant la Protohistoria (segles VIII-III aC): aspectos quantitatius i anàlisi de continguts, Arqueo Mediterrània 8, 283-291.

UBALDO, I. V.; GERMANO, R.; RAMOS DO EGYPTO, R. C.; NUNES, A.; PEREIRA, A. R. (2008): Profile of milk fatty acids from moxotó goats fed with different levels of manicoba (Manihot Glaziovii Muel Arg.) silage, Brazilian Archives of Biology and Technology 51 (6), 1163-1169. DOI: https://doi.org/10.1590/S1516-89132008000600011

VERA CRUZ, E. (2012). El yacimiento púnico-turdetano SE-M, Intervenciones arqueológicas en el Área del Proyecto Minero Cobre Las Cruces 1996-2011): de la Prehistoria a la época Contemporánea (provincia de Sevilla, España) (M. A. Hunt Ortiz coord.), Sevilla, 70-74.

WEINTEIN, J. A.; TAYLOR, S. L.; ROSENBERG M.; DEPETERS E. J. (2015): Whey protein gel composites in the diet of goats increased the omega- 3 and omega- 6 content of milk fat, Journal of Animal Physiology and Animal Nutrition (Berl) 2015 Aug 6, 1-12. 